\title{
GABA Expression Dominates Neuronal Lineage Progression in the Embryonic Rat Neocortex and Facilitates Neurite Outgrowth via $\mathrm{GABA}_{\mathrm{A}}$ Autoreceptor $/ \mathrm{Cl}^{-}$Channels
}

\author{
Dragan Maric, ${ }^{1}$ Qi-Ying Liu, ${ }^{1}$ Irina Maric, ${ }^{1}$ Sabeen Chaudry, ${ }^{1}$ Yoong-Hee Chang, ${ }^{1}$ Susan V. Smith, ${ }^{1}$ \\ Werner Sieghart, ${ }^{2}$ Jean-Marc Fritschy, ${ }^{3}$ and Jeffery L. Barker ${ }^{1}$ \\ ${ }^{1}$ Laboratory of Neurophysiology, National Institute of Neurological Disorders and Stroke, National Institutes of Health, \\ Bethesda, Maryland 20892, '2Department of Biochemical Psychiatry, University Clinic for Psychiatry, A-1090 Vienna, \\ Austria, and 3/nstitute of Pharmacology, University of Zurich, CH-8057 Zurich, Switzerland
}

\begin{abstract}
GABA emerges as a trophic signal during rat neocortical development in which it modulates proliferation of neuronal progenitors in the ventricular/subventricular zone (VZ/SVZ) and mediates radial migration of neurons from the VZ/SVZ to the cortical plate/subplate (CP/SP) region. In this study we investigated the role of GABA in the earliest phases of neuronal differentiation in the CP/SP. GABAergic-signaling components emerging during neuronal lineage progression were comprehensively characterized using flow cytometry and immunophenotyping together with physiological indicator dyes. During migration from the VZ/SVZ to the CP/SP, differentiating cortical neurons became predominantly GABAergic, and their dominant $\mathrm{GABA}_{\mathrm{A}}$ receptor subunit expression pattern changed from $\alpha 4 \beta 1 \gamma 1$ to $\alpha 3 \beta 3 \gamma 2 \gamma 3$ coincident with an increasing potency of $\mathrm{GABA}$ on $\mathrm{GABA}_{\mathrm{A}}$ receptor-mediated depolarization. $\mathrm{GABA}_{\mathrm{A}}$ autoreceptor/Cl
\end{abstract}

channel activity in cultured CP/SP neurons dominated their baseline potential and indirectly their cytosolic $\mathrm{Ca}^{2+}\left(\mathrm{Ca}^{2+}{ }_{\mathrm{c}}\right)$ levels via $\mathrm{Ca}^{2+}$ entry through L-type $\mathrm{Ca}^{2+}$ channels. Block of this autocrine circuit at the level of GABA synthesis, GABA receptor activation, intracellular $\mathrm{Cl}^{-}$ion homeostasis, or L-type $\mathrm{Ca}^{2+}$ channels attenuated neurite outgrowth in most GABAergic CP/SP neurons. In the absence of autocrine GABAergic signaling, neuritogenesis could be preserved by depolarizing cells and elevating $\mathrm{Ca}^{2+}{ }_{\mathrm{c}}$. These results reveal a morphogenic role for GABA during embryonic neocortical neuron development that involves $\mathrm{GABA}_{\mathrm{A}}$ autoreceptors and L-type $\mathrm{Ca}^{2+}$ channels.

Key words: embryonic; rat; development; cortical; neuritogenesis; GABA; GAD; FACS
GABAergic-signaling components emerge and become widespread during the embryonic period of vertebrate CNS development, indicating possible developmental roles for GABA [for a recent monograph, see Barker and Lauder (1998)]. GABA and its synthetic enzymes, the two isoforms of glutamic acid decarboxylase $\left(\mathrm{GAD}_{65}\right.$ and $\left.\mathrm{GAD}_{67}\right)$, appear throughout the embryonic rat neocortex together with $\mathrm{GABA}_{\mathrm{A}}$ receptor subunits, which form $\mathrm{Cl}^{-}$ion channels (Lauder et al., 1986; Van Eden et al., 1989; Cobas et al., 1991; Laurie et al., 1992; Poulter et al., 1992, 1993). During the development of embryonic neocortex, GABAergic cells are distributed in the ventricular/subventricular zone (VZ/ SVZ) containing proliferating precursors and progenitors, where $\alpha 4, \beta 1$, and $\gamma 1 \mathrm{GABA}_{\mathrm{A}}$ receptor subunit transcripts and proteins are predominantly expressed (Ma and Barker, 1995, 1998), and in the cortical plate/subplate $(\mathrm{CP} / \mathrm{SP})$ region containing differentiating neurons, many of which exhibit $\alpha 3, \beta 3$, and $\gamma 2$ receptor subunit transcripts and proteins (Maric et al., 1997).

Electrical recordings of cells in embryonic cortical slice preparations have shown that GABA depolarizes cells by activating

\footnotetext{
Received Aug. 22, 2000; revised Dec. 1, 2000; accepted Dec. 13, 2000.

We acknowledge Dr. Jung-Hwa Tao-Cheng and Virginia A. Tanner at the National Institute of Neurological Disorders and Stroke Electron Microscopy Facility (National Institutes of Health, Bethesda, MD) for providing their invaluable technical expertise and training in EM immunocytochemistry.

Correspondence should be addressed to Dr. Dragan Maric, Laboratory of Neurophysiology, National Institute of Neurological Disorders and Stroke, National Institutes of Health, Building 36, Room 2C-02, Bethesda, MD 20892. E-mail: maricd@ninds.nih.gov.

Copyright (C) 2001 Society for Neuroscience $\quad 0270-6474 / 01 / 212343-18 \$ 15.00 / 0$
}

$\mathrm{GABA}_{\mathrm{A}}$ receptor/Cl${ }^{-}$ion channels (LoTurco et al., 1995). The pharmacological properties of $\mathrm{GABA}_{\mathrm{A}}$ receptor-coupled $\mathrm{Cl}^{-}$ currents recorded in $\mathrm{VZ} / \mathrm{SVZ}$ neuronal progenitor cells and $\mathrm{CP} / \mathrm{SP}$ differentiating neurons appear to change, with GABA being more potent in depolarizing the progenitor population (Owens et al., 1999). GABA added to cortical slice preparations differentially modulates neural cell proliferation in the $\mathrm{VZ}$ and SVZ (LoTurco et al., 1995; Haydar et al., 2000). In vitro, GABA also acts like a chemoattractant and directs the migration of postmitotic neurons from the VZ/SVZ to the CP/SP via $\mathrm{GABA}_{\mathrm{B}}$ receptors (Behar et al., 1996, 1998, 2000). In addition, GABA can both stimulate random motility in $\mathrm{CP} / \mathrm{SP}$ neurons via $\mathrm{GABA}_{\mathrm{B}}$ receptor-coupled $\mathrm{Ca}^{2+}$ signals and attenuate their own movement via $\mathrm{GABA}_{\mathrm{A}}$ receptor $/ \mathrm{Cl}^{-}$channels, as neurons become arranged into primitive layers (Behar et al., 1998). Pharmacological activation of $\mathrm{GABA}_{\mathrm{A}}$ receptor $/ \mathrm{Cl}^{-}$channels expressed by growth cones fractionated from neurons in the developing cortex increases cytosolic $\mathrm{Ca}^{2+}$ levels via voltage-sensitive $\mathrm{L}$-type $\mathrm{Ca}^{2+}$ channels (Fukura et al., 1996), which can lead to $\mathrm{Ca}^{2+}$-dependent phosphorylation of specific proteins (Ohbayashi et al., 1998). These latter results suggest a morphogenic role for GABA related to the physiology of neurite outgrowth among embryonic cortical neurons.

In this study, we investigated the cellular distributions of GABAergic-signaling components emerging at the end of neurogenesis in the embryonic rat neocortex and examined the functional role of GABA on neurite outgrowth after radial migration of neurons into the $\mathrm{CP} / \mathrm{SP}$. GABAergic-signaling components, 
including the expression of $\mathrm{GAD}_{65}, \mathrm{GAD}_{67}, \mathrm{GABA}, \mathrm{GABA}_{\mathrm{A}}$, and $\mathrm{GABA}_{\mathrm{B}}$ receptor subunits, and GABAergic signals at $\mathrm{GABA}_{\mathrm{A}}$ receptor $/ \mathrm{Cl}^{-}$channels emerged in the $\mathrm{VZ}$ at the earliest stages of neuronal lineage progression. In $\mathrm{CP} / \mathrm{SP}$ neurons, autocrine GABAergic signals dominated their baseline membrane potential and cytosolic $\mathrm{Ca}^{2+}$ levels. This autocrine activity was critical to neurite outgrowth, because interruption of each component in the circuit markedly attenuated process formation and/or regeneration without altering cell survival.

Parts of this paper have been published previously (Maric et al., 1998a).

\section{MATERIALS AND METHODS}

\section{Cell preparation}

Experiments were performed on embryos recovered from timedpregnant Sprague Dawley rats (Taconic, Germantown, NY) during the last half of gestation. The embryonic age was determined by comparing the crown-rump lengths of embryos with previously published values (Hebel and Stromberg, 1986). The day of conception was taken as embryonic day 1 (E1). All of the research was performed in compliance with the Animal Welfare Act and the Public Health Service policy on Humane Care and Use of Laboratory Animals and was approved by the National Institute of Neurological Disorders and Stroke Animal Care and Use Committee.

Most of the study was focused on developing neocortical cells at E19. To obtain access to neuronal subpopulations before and after radial migration, 350- $\mu \mathrm{m}$-thick coronal sections of the brain at the level of the midposterior neocortex, which corresponded to coronal plates 9-12 (Altman and Bayer, 1995), were microdissected along the incipient white matter into a $\mathrm{CP} / \mathrm{SP}$ region and a VZ/SVZ zone, and the tissues were then optimally dissociated into single-cell suspensions, as described previously (Maric et al., 1997, 2000b). The cells were subsequently washed and finally resuspended at a density of $2 \times 10^{6}$ cells $/ \mathrm{ml}$ in a normal physiological medium (NPM) consisting of (in mM): $145 \mathrm{NaCl}, 5 \mathrm{KCl}$, $1.8 \mathrm{CaCl}_{2}, 0.8 \mathrm{MgCl}_{2}, 10$ glucose, and 10 HEPES, pH 7.3 (osmolarity, $290 \mathrm{mOsm}$ ). During the initial cell preparation and under some experimental conditions, NPM was supplemented with $1 \mathrm{mg} / \mathrm{ml}$ bovine serum albumin (NPM/BSA), which was obtained from Sigma (St. Louis, MO).

\section{Immunostaining protocols}

Immunolabeling of surface and cytoplasmic epitopes was performed in Dulbecco's PBS (Quality Biologicals, Gaithersburg, MD) supplemented with $1 \mathrm{mg} / \mathrm{ml}$ BSA (PBS/BSA). Unless stated otherwise, PBS/BSA was also used as a diluent for the preparation of working stocks of all primary and secondary antibodies. All immunoreactions were performed at room temperature (RT).

Immunofluorescent labeling of surface epitopes. To discriminate among the developing cortical cells progressing along neuronal and glial cell lineages, we used a mouse monoclonal class IgM anti-A2B5 antibody (Boehringer Mannheim, Indianapolis, IN) and a mixture of tetanus toxin fragment $\mathrm{C}$ (TnTx; Boehringer Mannheim) and a mouse monoclonal class IgG2b anti-TnTx antibody (obtained from Dr. William Habig, Food and Drug Administration, Bethesda, MD), as described previously (Maric et al., 1999a, 2000b). Briefly, acutely dissociated cells in suspension were double-immunoreacted with $1 \mu \mathrm{g} / \mathrm{ml}$ anti-A2B5 and TnTx/ anti-TnTx for $30 \mathrm{~min}$ and then washed in NPM, and the primary immunoreactions were visualized by immunostaining with $10 \mu \mathrm{g} / \mathrm{ml}$ phycoerythrin (PE)-conjugated goat anti-mouse IgM and PE/CY5conjugated goat anti-mouse IgG2b antibodies (Caltag, South San Francisco, CA) for an additional $30 \mathrm{~min}$.

Immunofluorescent labeling of cytoplasmic epitopes. To immunotype TnTx/A2B5-labeled populations further, we performed triple-staining protocols using antibodies specific for different components of the GABAergic-signaling pathway. These included rabbit polyclonal antiGABA (Sigma) and two anti-GAD antibodies specific for $\mathrm{GAD}_{65}$ and $\mathrm{GAD}_{67}$ isoforms (obtained from Dr. David L. Martin, State University of New York, Albany, NY). In addition, the expression of $13 \mathrm{GABA}_{\mathrm{A}}$ and $2 \mathrm{GABA}_{\mathrm{B}}$ receptor subunits was investigated in the TnTx/A2B5-labeled subpopulations using specific antibodies generated against appropriate synthetic peptides or fusion proteins (sequences of targeted amino acid residues are depicted in parentheses). $\mathrm{GABA}_{\mathrm{A}}$ receptor antibodies included guinea pig polyclonals specific for $\alpha 2(1-9)$ and $\alpha 3$ (1-15) subunits (obtained from Dr. Jean-Marc Fritschy, University of Zurich, Zurich, Switzerland) and rabbit polyclonals specific for $\alpha 1$ (1-9), $\alpha 4$ (379-421), $\alpha 5$ (2-10), $\alpha 6$ (429-434), $\beta 1$ (350-404), $\beta 2$ (351-405), $\beta 3$ (345-408), $\gamma 1$ $(324-366), \gamma 2(319-366), \gamma 3(322-372)$, and $\delta(1-44)$ subunits (obtained from Dr. Werner Sieghart, University Clinic for Psychiatry, Vienna, Austria); $\mathrm{GABA}_{\mathrm{B}}$ receptor antibodies included guinea pig polyclonals specific for R1 (both R1a and R1b isoforms) and R2 subunits (Chemicon, Temecula, CA). The characterization and specificity of the aforementioned antibodies have been described elsewhere (Benke et al., 1991, 1997; Buchstaller et al., 1991; Marksitzer et al., 1993; Martin and Rimvall, 1993; Mertens et al., 1993; Rimvall et al., 1993; Mossier et al., 1994; Todd et al., 1996; Sperk et al., 1997; Jones et al., 1998; Kaupmann et al., 1998; White et al., 1998; Durkin et al., 1999; Martin et al., 1999; Yung et al., 1999; Calver et al., 2000; Princivalle et al., 2000).

In short, the staining protocol was as follows. The cells were first surface labeled with anti-A2B5-PE and anti-TnTx-PE/CY5, then fixed in $4 \%$ paraformaldehyde (PF) for $30 \mathrm{~min}$, washed three times in PBS/BSA, and immunolabeled with appropriate dilutions of anti-GABA, anti$G D_{65}$, anti-GAD 67 , or one of the aforementioned $\mathrm{GABA}_{\mathrm{A}}$ or $\mathrm{GABA}_{\mathrm{B}}$ receptor subunit antibodies for $1 \mathrm{hr}$. The primary immunoreactions were visualized after a $30 \mathrm{~min}$ incubation with the appropriate fluorescein isothiocyanate (FITC)-conjugated donkey anti-rabbit or donkey antiguinea pig IgG secondary antibodies $(5-10 \mu \mathrm{g} / \mathrm{ml}$; Jackson ImmunoResearch, West Grove, PA). Control immunoreactions, in which the primary and/or the secondary antibodies were omitted during the staining protocol, were also performed. Nonspecific staining of these antibodies was minimized by a 30 min blocking step in PBS containing $10 \%(\mathrm{v} / \mathrm{v})$ normal rat serum and 10\% (v/v) normal donkey serum (Jackson ImmunoResearch). The same solution was also used as a diluent during the incubation steps with primary and secondary antibodies.

Flow-cytometic detection of fluorescently labeled epitopes. Surface and cytoplasmic immunoreactions among TnTx/A2B5-labeled subpopulations in suspension were quantified in 100,000-cell samples using the FACSTAR $^{+}$flow cytometer (Becton Dickinson, Mountain View, CA), as detailed previously (Maric et al., 1999a, 2000b). Briefly, the FITC, PE, and PE/CY5 fluorescence signals were excited by an argon ion laser (model 2016; Spectra-Physics, Mountain View, CA) tuned to obtain 500 $\mathrm{mW}$ power at $488 \mathrm{~nm}$, and the resulting fluorescence emissions were collected using bandpass filters set at $530 \pm 30,575 \pm 25$, and $670 \pm 20$ $\mathrm{nm}$, respectively. Cell Quest Analysis software (Becton Dickinson) was used to quantify the fluorescence signal intensities among the immunolabeled subpopulations.

EM immunocytochemistry. The distribution of GABA immunoreactivity at the subcellular level was examined using an immunogold labeling protocol in conjunction with transmission electron microscopy. Acutely prepared $\mathrm{CP} / \mathrm{SP}$ neurons were allowed to adhere on eight-well plastic chamber slides (Nunc, Naperville, IL) and were then cultured for $24 \mathrm{hr}$ in Neurobasal medium supplemented with B27 additives (Life Technologies, Gaithersburg, MD). The cells were then fixed in $4 \%$ PF (EM grade; EMS, Ft. Washington, PA) for 30 min, washed three times in PBS, permeabilized with PBS/BSA/0.1\% saponin (Sigma), which also served as the diluent for primary and secondary antibodies, and immunoreacted with $2 \mu \mathrm{g} / \mathrm{ml}$ rabbit anti-GABA antibody for $1 \mathrm{hr}$. The primary immunoreaction was visualized with $5 \mu \mathrm{g} / \mathrm{ml}$ goat anti-rabbit secondary antibody (Fab' fragment) conjugated to a $1.4 \mathrm{~nm}$ gold particle (Nanoprobes, Stonybrook, NY), followed by a silver enhancement and EM processing steps as detailed previously (Tanner et al., 1996). Control cells excluded one of the following: (1) primary antibody, (2) secondary antibody, or (3) primary and secondary antibody.

Immunohistochemistry. In some experiments, E19 rat brains were fixed in $4 \% \mathrm{PF}$ for $4 \mathrm{hr}$, cryoprotected in $30 \%$ sucrose for $3-5 \mathrm{~d}$ at $4{ }^{\circ} \mathrm{C}$, and frozen in liquid nitrogen-cooled isopentane (Fisher Scientific, Fair Lawn, NJ). Twenty-micrometer-thick coronal sections were cut using a Jung Frigocut cryostat (model 2800E; Leica, Nussloch, Germany) and then dried at RT for $1 \mathrm{hr}$ and immunoreacted with appropriate dilutions of the aforementioned $\mathrm{GABA}_{\mathrm{A}}$ or $\mathrm{GABA}_{\mathrm{B}}$ receptor subunit-specific antibodies overnight. For immunohistochemistry, all antibodies were diluted in PBS containing $10 \%(\mathrm{v} / \mathrm{v})$ normal rat serum and $10 \%(\mathrm{v} / \mathrm{v})$ normal donkey serum, as described above, to prevent nonspecific binding. In control slides, the primary antibodies were substituted with diluent only. The sections were then incubated for $1 \mathrm{hr}$ with biotinylated donkey antibodies against appropriate species (Jackson ImmunoResearch), which served as secondary immunoreagents. Finally, the cells were reacted for $1 \mathrm{hr}$ with streptavidin-conjugated horseradish peroxidase (Jackson ImmunoResearch) and developed in 3-amino-9-ethyl carbazole (AEC) substrate 
(Sigma; $25 \mathrm{mg}$ of AEC in $100 \mathrm{ml}$ of acetate buffer) with $0.01 \% \mathrm{H}_{2} \mathrm{O}_{2}$ for 10-15 $\mathrm{min}$ at RT. The slides were then coverslipped, and the sections were imaged under a transmission light microscope using the NIH Image software (developed at the National Institutes of Health and available on the Internet at http://rsb.info.nih.gov/nih-image/) on the Macintosh workstation.

\section{Flow-cytometric recordings of calcium and potentiometric signals}

E19 cells immunolabeled with TnTx-PE/CY5 and A2B5-PE were stained with either potentiometric or $\mathrm{Ca}^{2+}$ indicator dyes to record their membrane potential or cytosolic $\mathrm{Ca}^{2+}\left(\mathrm{Ca}^{2+}{ }_{\mathrm{c}}\right)$ levels under resting baseline conditions in NPM and in response to various agonists, as described previously (Maric et al., 2000b). Briefly, to record membrane potential (MP), immunolabeled cells were resuspended at a density of $2 \times 10^{6}$ cells/ml and stained with $200 \mathrm{~nm}$ bis-(1,3-dibutylbarbituric acid)trimethine oxonol (Molecular Probes, Eugene, OR) for $10 \mathrm{~min}$ at RT to allow complete equilibration of the negatively charged dye with cell plasma membranes before recording MP values. Alternatively, the immunolabeled cells were loaded with $100 \mathrm{~nm}$ fluo-3 AM, a Ca ${ }^{2+}$ indicator dye (Molecular Probes), for $20 \mathrm{~min}$ at RT and then washed to remove unincorporated dye and resuspended in NPM for $30 \mathrm{~min}$ to permit deesterification before recording $\mathrm{Ca}^{2+}{ }_{\mathrm{c}}$ levels. Both oxonol and fluo-3 were excited at $488 \mathrm{~nm}$, and their fluorescence emissions were detected with a bandpass filter set at $525 \pm 15 \mathrm{~nm}$. In triple-staining experiments, the spectral overlap of fluo-3 or oxonol fluorescence emissions into the PE detection window and of PE fluorescence signals into the PE/CY5 detection window was electronically compensated at the preamplifier stage.

Modal values in the oxonol and fluo-3 fluorescence signal distributions were calibrated in terms of MP or $\left[\mathrm{Ca}^{2+}\right]_{\mathrm{c}}$ using previously established protocols (Maric et al., 1998b,c, 1999a). Typically, resting MP and $\mathrm{Ca}^{2+}{ }_{\mathrm{c}}$ levels were randomly recorded from 100,000 TnTx/A2B5-immunoidentified cells at the rate of $\sim 2000$ cells/sec. The modal (approximate mean in symmetrically distributed signals) MP or $\mathrm{Ca}^{2+}{ }_{\mathrm{c}}$ values expressed by different subpopulations were quantified by gating electronically on TnTx and/or A2B5 immunofluorescence signals. This combined surface-labeling-and-indicator-dye-recording strategy allowed us to profile the physiological properties of virtually all neocortical cell phenotypes (i.e., neural precursors, neuronal and neuroglial progenitors, and differentiating neurons) in suspension in a rapid and statistically complete manner (Maric et al., 2000b). TnTx/A2B5 labeling itself did not trigger detectable changes in either baseline membrane potential or $\mathrm{Ca}^{2+}{ }_{\mathrm{c}}$ (data not shown).

\section{Dual video microscopic imaging of calcium and potentiometric signals}

Dual-indicator dye digital video microscopic imaging of $\mathrm{Ca}^{2+}{ }_{\mathrm{c}}$ and membrane potential was performed on fields of 20-30 isolated cells cultured from the CP/SP, as detailed elsewhere (Maric et al., 2000b). Briefly, the cells were plated at a density of $2 \times 10^{4}$ cells $/ \mathrm{cm}^{2}$ on poly-D-lysine-coated coverslips, which were photoetched with an $\alpha$-numeric grid (Bellco Glass, Inc., Vineland, NJ), preglued to $35 \mathrm{~mm}$ tissue culture dishes (MatTek Corporation, Ashland, MA), and cultured for $24-48 \mathrm{hr}$ in Neurobasal/B27 medium. At the end of culture, the cells were loaded with $2 \mu \mathrm{M}$ fura-2 AM (Molecular Probes) for $1 \mathrm{hr}$ at $37^{\circ} \mathrm{C}$, washed in NPM, and stained for $10 \mathrm{~min}$ at RT with $500 \mathrm{~nm}$ oxonol. Because oxonol equilibrates dynamically according to the cell membrane potential, the dye was included in all recording solutions, which were delivered to the $150 \mu \mathrm{l}$ recording chamber using gravity-driven perfusion at $\sim 2 \mathrm{ml} / \mathrm{min}$.

The cells were imaged using the Attofluor RatioVision workstation (Atto Instruments, Rockville, MD) equipped with an Axiovert 135 inverted microscope (Carl Zeiss, Thornwood, NY) and an intensified ICCD camera (Atto Instruments). The indicator dyes were sequentially excited at $1 \mathrm{sec}$ intervals with a $100 \mathrm{~W}$ mercury arc lamp filtered at $488 \pm$ $5 \mathrm{~nm}$ for oxonol and at $334 \pm 5$ and $380 \pm 5 \mathrm{~nm}$ for fura-2. Fluorescence emissions were acquired through a $510 \mathrm{~nm}$ dichroic mirror and a $520 \mathrm{~nm}$ long-pass filter set (Chroma Technology Corporation, Brattleboro, VT). Regions of interest (ROIs) were drawn electronically around individual cell bodies, and indicator dye fluorescence signals of each ROI were digitized with a Matrox image processing board and then plotted as line graphs using Attograph for Windows analysis software (Atto Instruments). Oxonol and fura-2 fluorescence signal distributions were calibrated in terms of MP or $\left[\mathrm{Ca}^{2+}\right]_{\mathrm{c}}$ using previously established protocols (Maric et al., 1998c, 2000b).
After imaging, the field of recorded cells was photographed with a 35 $\mathrm{mm}$ camera using phase-contrast optics to reveal their location with respect to the underlying alphanumeric grid. The cells were then washed in NPM to remove the oxonol dye and then immunostained with antiA2B5-PE, anti-TnTx-PE/CY5, and anti-GABA-FITC, as described above. In this way, the physiological properties of individual cells at membrane and cytoplasmic levels could be recorded simultaneously and then correlated with their differentiation state.

\section{Electrophysiology}

Before recording, the Neurobasal culture medium was replaced with Tyrode's solution containing (in mM): $145 \mathrm{NaCl}, 5.4 \mathrm{KCl}, 1.8 \mathrm{CaCl}_{2}, 0.8$ $\mathrm{MgCl}_{2}, 10$ glucose, and $10 \mathrm{HEPES}-\mathrm{NaOH}, \mathrm{pH} 7.4$ (310 mOsm). Standard patch-clamp recordings (Hamill et al., 1981) were made with pipettes pulled in three stages from 1.5 -mm-outer diameter glass capillary tubes (WPI, Sarasota, FL) with a computer-controlled pipette puller (BB-CHPC; Mecanex; Geneva, Switzerland). These pipettes had a resistance of 3-5 $\mathrm{M} \Omega$ when filled with internal solution composed of (in $\mathrm{mm}$ ): 145 CsCl, $2 \mathrm{MgCl}_{2}, 0.1 \mathrm{CaCl}_{2}, 1.1$ EGTA, 5 HEPES, 5 ATP (potassium salt), and 5 phosphocreatine, $\mathrm{pH} 7.2$ (290 mOsm). Whole-cell currents were recorded with an L/M EPC-7 patch-clamp amplifier (Medical Systems Corporation, Greenvale, NY) at a gain of $5 \mathrm{mV} / \mathrm{pA}$ for whole-cell current and $100 \mathrm{mV} / \mathrm{pA}$ for single-channel current. Series resistance was compensated for $>70 \%$. Current signals were stored on videocassettes via a videocassette recorder and a VR-100 digital recorder (Instrutech) for later off-line digitization with Digidata 1200 (Axon Instruments, Foster City, CA) and analysis with Pclamp V6.0 (Axon Instruments) on a Pentium-based personal computer. All recordings were performed at RT $\left(22-25^{\circ} \mathrm{C}\right)$ on a Nikon inverted microscope. For superfusing the cells, we used a perfusion system composed of a locally made controller and miniature electric solenoid valves (The Lee Company, Essex, CT) that allows fast switching ( $<200 \mathrm{msec}$ complete solution exchange time) among different solutions (Liu et al., 1999). The perfusion rate $(\sim 0.3-0.5 \mathrm{ml} / \mathrm{min})$ was controlled by the air pressure applied to the solution reservoirs.

\section{Pharmacology}

We used both flow-cytometric and dual-imaging strategies to examine the emergence and characterize the properties of GABAergic-signaling components in entire populations and in single cells, respectively. Pharmacological experiments were performed by exposing the cells to GABA, muscimol, bicuculline (BIC), picrotoxin (PIC), baclofen, and/or saclofen (SAC) to reveal expression of $\mathrm{GABA}_{\mathrm{A}} / \mathrm{Cl}^{-}$channels and $\mathrm{GABA}_{\mathrm{B}} / \mathrm{Ca}^{2+}$ channels. The cells were also exposed to furosemide, which blocks $\mathrm{Cl}^{-}$ion transport into cells, 3-mercaptopropionic acid (3-MPA), which blocks GAD activity, and nitrendipine (NTDP), which blocks voltage-dependent $\mathrm{L}$-type $\mathrm{Ca}^{2+}$ channels. In some experiments, the cells were exposed to ionomycin, a $\mathrm{Ca}^{2+}$ ionophore, 6-cyano-7nitroquinoxaline-2,3-dione (CNQX), and/or 2-amino-5-phosphonovaleric acid (APV), respective antagonists at ionotropic glutamate receptors of the AMPA/kainate or NMDA subtype, atropine and/or suramin, respective antagonists of muscarinic acetylcholine receptors and P2 purinoreceptors, and tetrodotoxin (TTX), a blocker of voltagesensitive $\mathrm{Na}^{+}$channels. Muscimol and APV were obtained from Research Biochemicals (Natick, MA). All other reagents were purchased from Sigma. Some recordings were performed in NPM/BSA, which effectively reduced the effects of endogenous GABA signaling (see Results) and adequately stabilized the baseline cell properties during the experimental period. Otherwise, the recordings were performed in NPM. All experiments were conducted at RT.

\section{RESULTS}

\section{$\mathrm{GABA}_{\mathrm{A}}$ receptor subunit expressions change with neuronal lineage development}

We identified subpopulations of proliferating neural precursors, neuronal and neuroglial progenitors, and differentiating neurons in the embryonic rat neocortex using recently developed surfacelabeling techniques (Maric et al., 2000b). Cells were identified on the basis of their surface expression of neuron-specific tetanus toxin (TnTx) and progenitor-selective A2B5 markers (Fig. 1). Microdissection of the neocortex into $\mathrm{VZ} / \mathrm{SVZ}$ and $\mathrm{CP} / \mathrm{SP}$ regions further resolved the TnTx/A2B5-immunoidentified cells according to their anatomical location. Four cell phenotypes 
Figure 1. $\mathrm{GABA}_{\mathrm{A}}$ receptor subunits are differentially expressed during neuronal lineage progression. Using quantitative flow cytometry of TnTx/A2B5 surface-labeling patterns and intensities in conjunction with microdissection, we identified the E19 neocortical cells as neural precursors (DN), neuroglial (SPA2B5) or neuronal (SP-TnTx ${ }^{\text {lo }}$ or DP$\mathrm{TnTx}^{10}$ ) progenitors from the $\mathrm{VZ} / \mathrm{SVZ}$, or postmitotic/postmigratory differentiating neurons (SP-TnTx ${ }^{\text {hi }}$ or DP$\mathrm{TnTx}^{\text {hi }}$ ) from the CP/SP regions (Maric et al., 2000b). After surface phenotyping, the cells were fixed and processed for the expression of $13 \mathrm{GABA}_{\mathrm{A}}$ receptor and $2 \mathrm{GABA}_{\mathrm{B}}$ receptor subunits (see Materials and Methods). Left, As an example, the log-log dot density plots in pseudocolor show the TnTx/A2B5 labeling pattern characteristic of E19 neocortical cells and the distributions of the $\gamma 3$ $\mathrm{GABA}_{\mathrm{A}}$ receptor subunit in the context of either surface label. Boundaries (crosshairs) between labeled and unlabeled cells and between cells expressing low and high levels of TnTx labeling (TnTx ${ }^{\text {lo }}$ and $\operatorname{TnTx}^{\text {hi }}$ ) have been drawn empirically to quantify the percentages of cells in each subpopulation. Middle, Right, The bar graphs summarize the percentage (means \pm SEM) of immunopositive cells in each subpopulation from three independent experiments. Approximately 35-65\% of DN neural precursor cells in the $\mathrm{VZ} / \mathrm{SVZ}$ express $\alpha 4, \beta 1, \gamma 1, \gamma 3$, or $\delta \mathrm{GABA}_{\mathrm{A}}$ receptor subunits (black bars) and both $\mathrm{GABA}_{\mathrm{B}}$ $\mathrm{R} 1$ and $\mathrm{R} 2$ receptor subunits (white bars), whereas SP-A2B5 neuroglial progenitors are virtually devoid of GABA Anti- $\gamma 3$ GABA $_{\mathbf{A}}$ R Subunit-FITC are $\alpha 3^{+}, \beta 2^{+}$, or $\gamma 2^{+}$. Many of these cells $(60-75 \%)$ also express both GABA $_{\mathrm{B}}$ receptor subunits. Some DP-TnTx ${ }^{10}$ neuronal progenitors $(20-40 \%)$ express $\alpha 4, \beta 1$, or $\gamma 1$ subunits, and $\sim 15 \%$ express both $\mathrm{GABA}_{\mathrm{B}}$ subunits. Almost all SP-TnTx ${ }^{\text {hi }}$ neurons $(85-95 \%)$ from the CP/SP are $\alpha 3^{+}, \beta 3^{+}, \gamma 2^{+}$, or $\gamma 3^{+}$, as are many DP-TnTx ${ }^{\text {hi }}$ neurons $(55-75 \%)$. Approximately half of the SP-TnTx ${ }^{\text {hi }}$ neurons exhibit GABA ${ }_{B}$ receptor subunits, whereas only few DP-TnTx ${ }^{\text {hi }}$ neurons $(\sim 10 \%)$ express GABA $_{\mathrm{B}}$ receptors. None of the neocortical populations express $\alpha 1$ and $\alpha 6 \mathrm{GABA}_{\mathrm{A}}$ receptor subunits at E19.
E19 Whole Neocortex
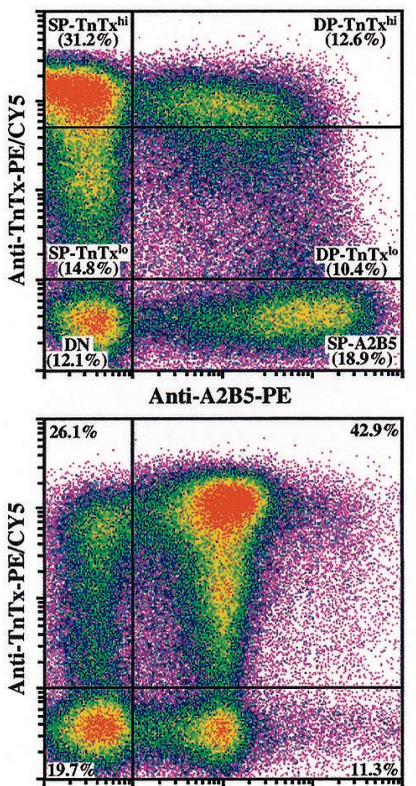

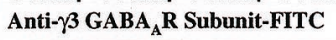

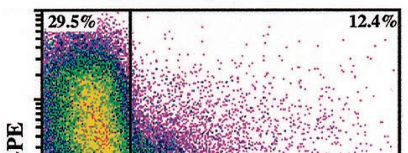

동

突

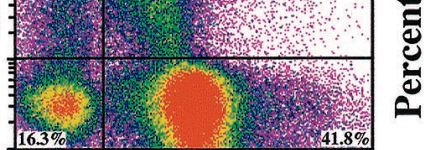

A
Cortical Plate/Subplate Regions

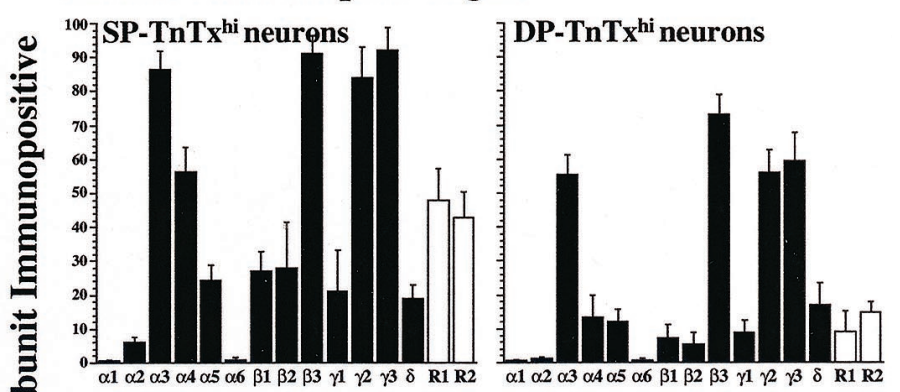

Ventricular/Subventricular Zones
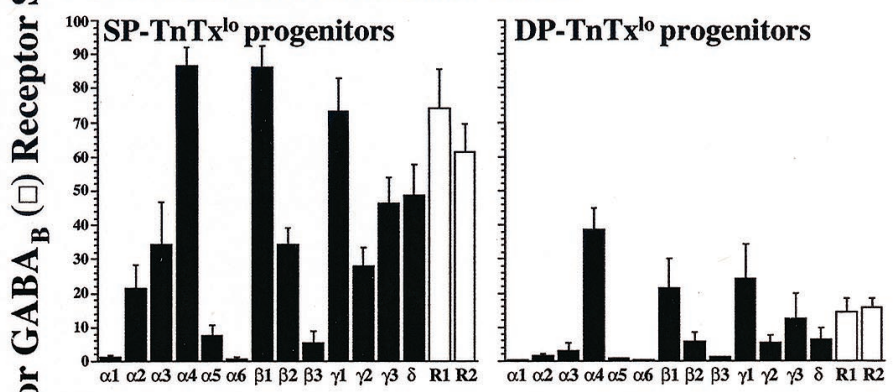

${ }^{100} \mathrm{7DN}$ neural precursors

SP-A2B5 progenitors

हैं

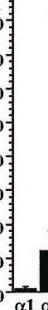

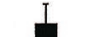

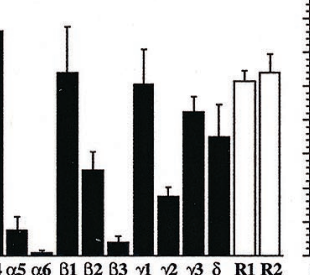

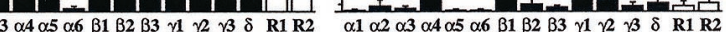
GABA Receptor Subunit Antibody composed the VZ/SVZ (see Maric et al., 2000b): neural precursors not labeled with TnTx or A2B5 [ $\mathrm{TnTx}^{-} \mathrm{A} 2 \mathrm{~B} 5^{-}$, doublenegative (DN)], neuroglial progenitors labeled only with A2B5 [single-positive for A2B5 (SP-A2B5)], and two subpopulations of neuronal progenitors, one that labeled with TnTx at low intensity $\left(\mathrm{SP}-\mathrm{TnTx}^{10}\right)$ and the other that stained double-positive for both TnTx at low intensity and A2B5 (DP-TnTx ${ }^{10}$ ). In contrast, two subpopulations of differentiating neurons predominated in the $\mathrm{CP} / \mathrm{SP}$ region: neurons that were labeled with $\mathrm{TnTx}$ at high intensity (SP-TnTx ${ }^{\text {hi }}$ ) and neurons that were double-positive for both TnTx at high intensity and A2B5 (DP-TnTx ${ }^{\text {hi }}$ ).

After microdissection and surface phenotyping with TnTx and $\mathrm{A} 2 \mathrm{~B} 5$, the cells were fixed and immunostained for $13 \mathrm{GABA}_{\mathrm{A}}$ receptor $(\alpha 1-6, \beta 1-3, \gamma 1-3$, and $\delta)$ and $2 \mathrm{GABA}_{\mathrm{B}}$ receptor (R1 and R2) subunits, and the resulting immunoreactions were quantified by flow cytometry. The data revealed changing patterns of $\mathrm{GABA}_{\mathrm{A}}$ receptor subunit expressions among the TnTx/A2B5immunoidentified subpopulations, which were coincident with neuronal maturation (Fig. 1). Approximately half of the $\mathrm{TnTx}^{-} \mathrm{A} 2 \mathrm{~B} 5{ }^{-}$neural precursor cells expressed immunodetectable $\alpha 4, \beta 1, \gamma 1$, or $\gamma 3 \mathrm{GABA}_{\mathrm{A}}$ receptor subunits and both $\mathrm{GABA}_{\mathrm{B}}$ receptor $\mathrm{R} 1$ and $\mathrm{R} 2$ subunits. The expression of $\alpha 4, \beta 1$, or $\gamma 1$ subunits became quite widespread in $>75 \%$ of SP-TnTx ${ }^{\text {lo }}$ neuronal progenitors in the VZ/SVZ, 30-50\% of which also exhibited $\alpha 3, \beta 2, \gamma 2, \gamma 3$, or $\delta$ subunit immunoreactivity. The trio of $\alpha 4, \beta 1$, and $\gamma 1 \mathrm{GABA}_{\mathrm{A}}$ receptor subunits was the only one detected at significant levels in $20-40 \%$ of DP-TnTx ${ }^{10}$ neurons. However, as DP-TnTx ${ }^{\text {lo }}$ progenitors became DP-TnTx ${ }^{\text {hi }}$ differentiating neurons, after migration to the $\mathrm{CP} / \mathrm{SP}$ region, the expression of $\alpha 4, \beta 1$, or $\gamma 1 \mathrm{GABA}_{\mathrm{A}}$ receptor subunits became significantly reduced, whereas the expression of $\alpha 3, \beta 3, \gamma 2$, or $\gamma 3$ $\mathrm{GABA}_{\mathrm{A}}$ receptor subunits became predominant in most (55$75 \%$ ) of these cells. The trio of $\alpha 4, \beta 1$, and $\gamma 1$ subunit expression was likewise quite reduced among SP-TnTx ${ }^{\text {hi }}$ neurons in the $\mathrm{CP} / \mathrm{SP}$ region compared with $\mathrm{SP}-\mathrm{TnTx}^{10}$ neuronal progenitors in the VZ/SVZ. For example, $\alpha 4$ decreased from $\sim 90$ to $\sim 55 \%$ in relative abundance, $\beta 1$ decreased from $\sim 85$ to $\sim 25 \%$, and $\gamma 1$ decreased from $\sim 75$ to $\sim 20 \%$. In addition, $\delta \mathrm{GABA}_{\mathrm{A}}$ receptor subunit expression decreased from $\sim 50 \%$ in $\mathrm{SP}^{-\mathrm{TnTx}^{10}}$ neuronal progenitors to $\sim 20 \%$ in SP-TnTx ${ }^{\text {hi }}$ neurons. Like DP-TnTx ${ }^{\text {hi }}$ neurons, the great majority of SP-TnTx ${ }^{\text {hi }}$ neurons (85-95\%) were $\alpha 3^{+}, \beta 3^{+}, \gamma 2^{+}$, or $\gamma 3^{+}$. Both $\mathrm{GABA}_{\mathrm{B}}$ receptor subunits were expressed by $\sim 50 \%$ of the SP-TnTx ${ }^{\text {hi }}$ neurons. Neither $\alpha 1$ nor $\alpha 6$ subunits were immunodetectable in any subpopulation, whereas $\alpha 5$ subunit was expressed in a minor proportion $(\leq 20 \%)$ of each 

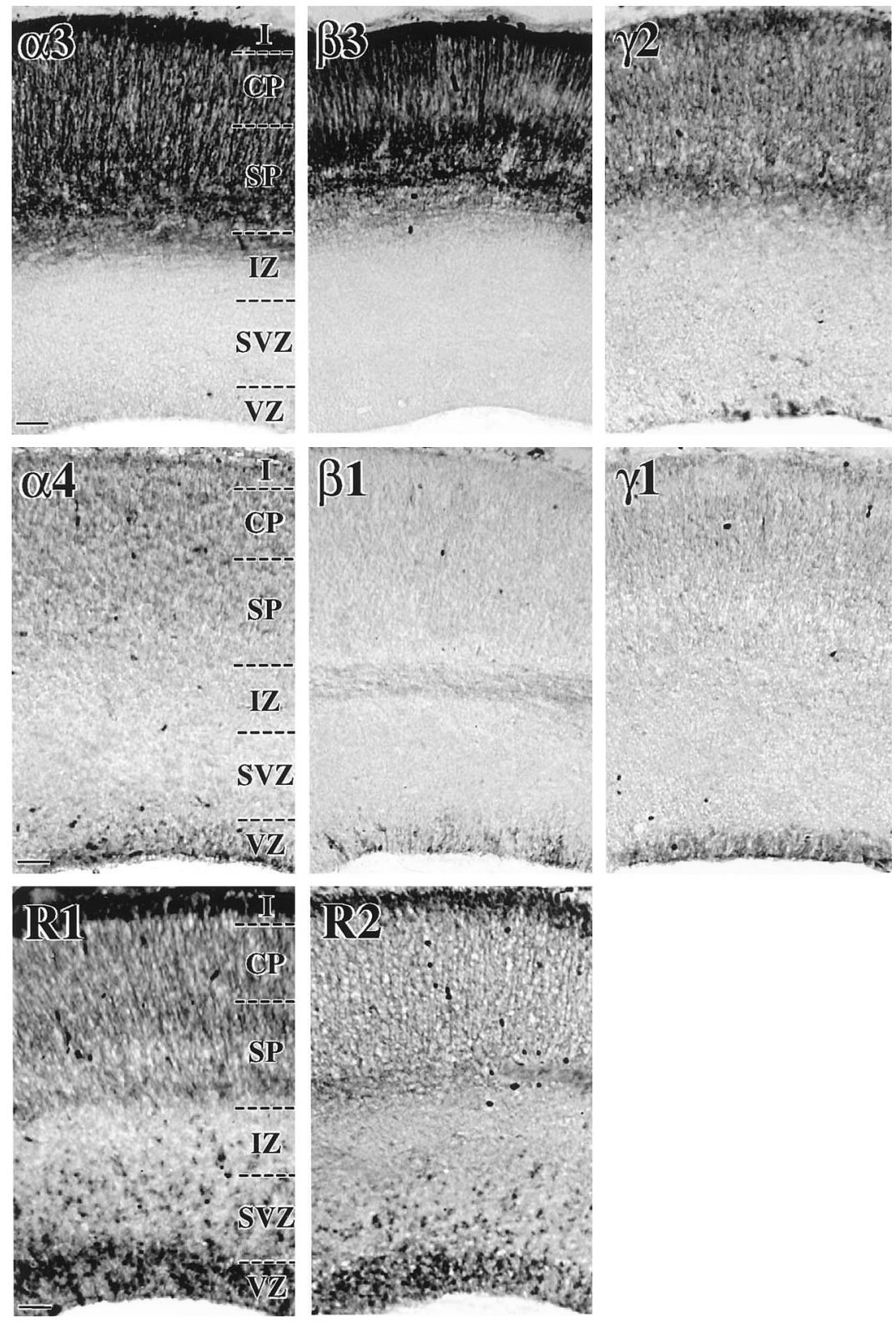

Figure 2. Differential anatomical distributions of $\mathrm{GABA}_{\mathrm{A}}$ and $\mathrm{GABA}_{\mathrm{B}}$ receptor subunits in the developing rat neocortex at the end of neurogenesis. Coronal sections $(12 \mu \mathrm{m}$ thick) of E19 rat neocortex were immunostained with antibodies specific for $\alpha 3, \alpha 4, \beta 1, \beta 3, \gamma 1$, or $\gamma 2$ subunits of the $\mathrm{GABA}_{\mathrm{A}}$ receptor and with antibodies specific for R1 or R2 subunits of the $\mathrm{GABA}_{\mathrm{B}}$ receptor, and the resulting immunoreactions were visualized with a peroxidase endpoint. The data show that $\alpha 3$ and $\beta 3$ subunit immunoreactivities are confined almost exclusively to the subplate (SP), CP, and layer I, with cell bodies and radiating processes both intensely stained. The distribution of $\gamma 2$ subunit immunoreactivity is also primarily restricted to these regions, but immunopositive cells can also be detected in the VZ and SVZ. In contrast, $\beta 1$ and $\gamma 1$ immunoreactivities are almost completely confined to cells in the VZ, although $\beta 1$ expression is also evident in the intermediate zone and faint $\gamma 1$ signals can be detected in the CP. The distribution of $\alpha 4$ subunit immunoreactivity is most intense in the VZ, with signals also present in the SP, CP, and layer I. $\mathrm{GABA}_{\mathrm{B}}$ receptor R1 and R2 subunit immunoreactivities show similar distributions in the VZ, SVZ, IZ, SP, CP, and layer I. Scale bars, $50 \mu \mathrm{m}$. IZ, Intermediate zone; $S P$, subplate.
$\mathrm{TnTx}^{+}$subpopulation. SP-A2B5 neuroglial progenitors in the $\mathrm{VZ} / \mathrm{SVZ}$ did not express $\mathrm{GABA}_{\mathrm{A}}$ and $\mathrm{GABA}_{\mathrm{B}}$ receptors.

These results demonstrate changing patterns of $\mathrm{GABA}_{\mathrm{A}}$ and relatively constant expressions of $\mathrm{GABA}_{\mathrm{B}}$ receptor subunit immunoreactivities during neuronal lineage progression. The expression of $\alpha 4, \beta 1, \gamma 1$, and $\delta \mathrm{GABA}_{\mathrm{A}}$ receptor subunits decreased as neurons migrated from the $\mathrm{VZ} / \mathrm{SVZ}$ to the $\mathrm{CP} / \mathrm{SP}$, where $\alpha 3$, $\beta 3, \gamma 2$, and $\gamma 3 \mathrm{GABA}_{\mathrm{A}}$ receptor subunits predominated.

The changing $\mathrm{GABA}_{\mathrm{A}}$ receptor subunit expressions quantified during neuronal lineage progression led us to identify their distributions in the intact anatomy of the neocortex at E19. The anatomical distributions corresponded well to the results derived from quantitative flow-cytometric analyses of microdissected subpopulations. For example, subunits dominant among CP/SP dissociates (e.g., $\alpha 3, \beta 3, \gamma 2$ ) were readily detected in the $\mathrm{CP} / \mathrm{SP}$ region with intense immunoreaction signals distributed among both cell bodies and radiating processes (Fig. 2). However, there was little, if any, detectable expression of these subunits in the VZ/SVZ. Subunits dominant among VZ/SVZ dissociates (e.g., $\alpha 4, \beta 1, \gamma 1)$ were found primarily but not exclusively in the VZ (e.g., $\alpha 4$ ). The distributions of these $\mathrm{GABA}_{\mathrm{A}}$ receptor subunit proteins parallel those of the corresponding transcripts, as reported previously (Poulter et al., 1993; Ma and Barker, 1995). Together, these results identify the different anatomical distributions of cells with evolving $\mathrm{GABA}_{\mathrm{A}}$ receptor subunit expression patterns, which could form functional $\mathrm{GABA}_{\mathrm{A}}$ receptor $/ \mathrm{Cl}^{-}$ channels.

In contrast to the more restricted distributions of the aforementioned $\mathrm{GABA}_{\mathrm{A}}$ receptor subunits, the anatomical distribution of $\mathrm{GABA}_{\mathrm{B}}$ receptor $\mathrm{R} 1$ and $\mathrm{R} 2$ subunits was relatively widespread throughout the developing neocortex at E19 (Fig. 2), with the immunoreactions for each subunit detected in the VZ/ $\mathrm{SVZ}$ and $\mathrm{CP} / \mathrm{SP}$ as well as on putative migrating neurons in the IZ. These findings indicate that these $\mathrm{GABA}_{\mathrm{B}}$ receptor subunits are expressed in both early and late stages of cortical neuron development. In addition, the immunohistochemical distribution of each $\mathrm{GABA}_{\mathrm{B}}$ receptor subunit in the E19 neocortex appeared to be quite similar, suggesting that these receptor subunits are 
Figure 3. $\mathrm{GAD}_{65}, \mathrm{GAD}_{67}$, and GABA expression is restricted to neuronal lineage development. After microdissection and immunophenotyping with $\operatorname{TnTx} /$ A2B5, the cells were fixed and immunostained with antibodies specific for $\operatorname{GAD}_{65}(A 1, A 2), \operatorname{GAD}_{67}(B 1, B 2)$, or GABA $(C 1, C 2)$, and the immunoreactions were quantified by flow cytometry. $A 1-C 1$, The frequency histogram plots illustrate the highly contrasting immunoreactivities, with the percentage of immunopositive cells depicted in parentheses, between SP-A2B5 neuroglial progenitors in the VZ/SVZ (left) and differentiating SP-TnTx ${ }^{\text {hi }}$ neurons in the $\mathrm{CP} / \mathrm{SP}$ (right). The Control frequency histogram represents the immunostaining reaction with secondary antibody in the absence of primary antibody. $A 2-C 2$, The bar graphs represent the percentage of immunopositive cells (means \pm SEM from 3 independent experiments) in the six subpopulations studied. $\mathrm{GAD}_{65^{-}}$and $\mathrm{GAD}_{67}$-immunoreactive cells exhibit quite similar distributions among the subpopulations, with the expression confined primarily to DN neural precursor cells and $\mathrm{TnTx}^{+}$neuronal progenitors and differentiating neurons. GABAimmunoreactive cells are also primarily confined to DN neural precursor cells and cells progressing along the neuronal lineage. More than $65 \%$ of SP-TnTx ${ }^{10}$ neuronal progenitors in the VZ/SVZ and $\sim 90 \%$ of SP-TnTx ${ }^{\text {hi }}$ neurons in the $\mathrm{CP} / \mathrm{SP}$ are GABAergic $(C 2)$.
A1

VZ/SVZ
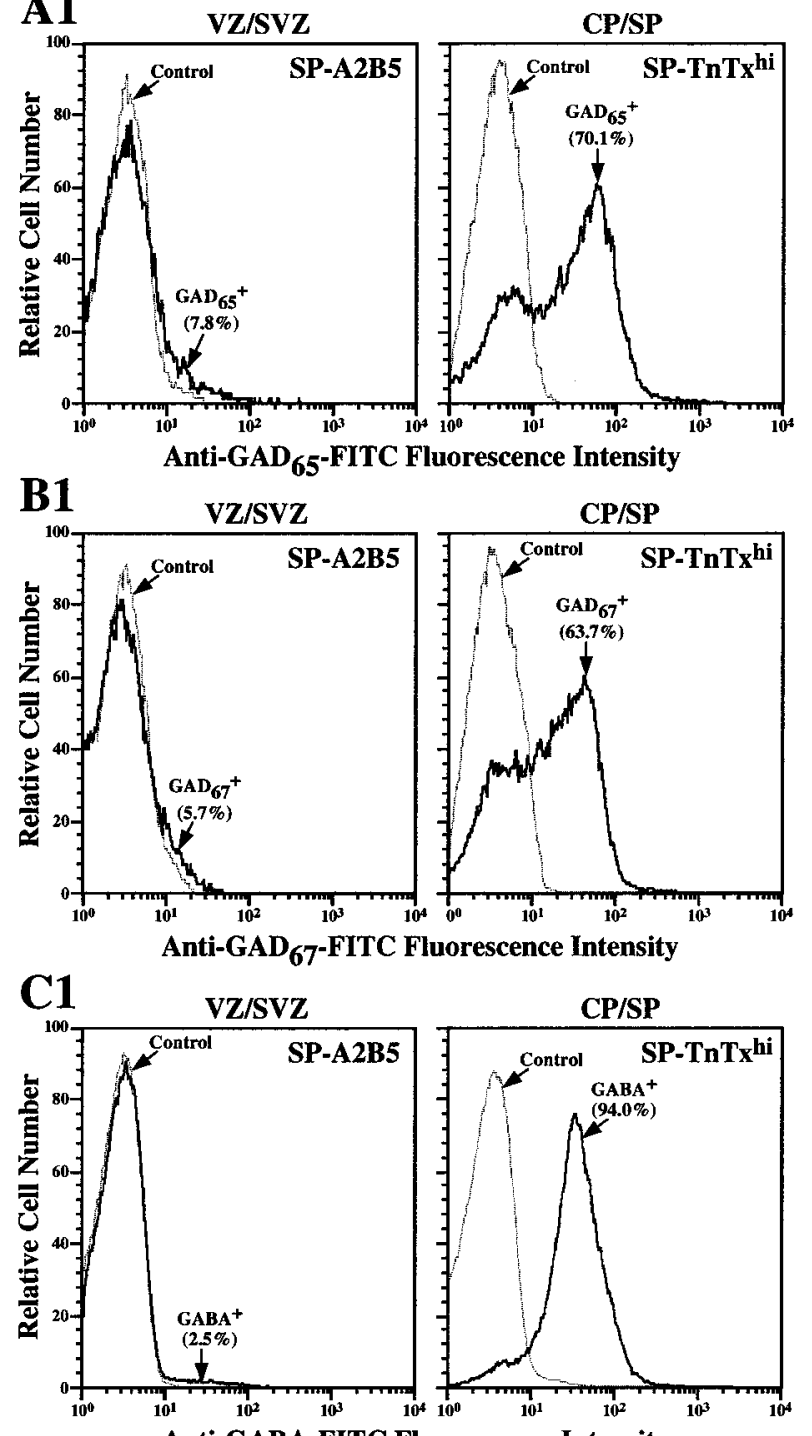

Anti-GABA-FITC Fluorescence Intensity
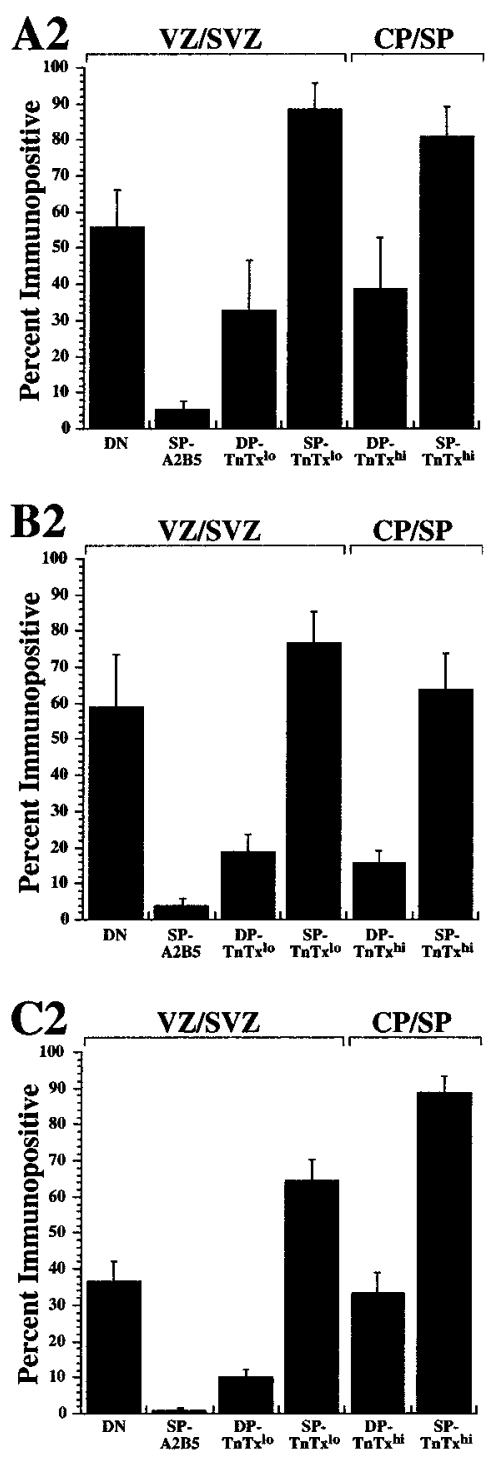

coexpressed and probably constitute a heteromeric complex, which has been implicated in composing functional $\mathrm{GABA}_{\mathrm{B}}$ receptors in the CNS (Jones et al., 1998; Bowery and Enna, 2000; Couve et al., 2000). Functional $\mathrm{GABA}_{\mathrm{B}}$ receptors have been shown previously to mediate cortical neuronal migration from the VZ/SVZ to the CP/SP in rat neocortex over E17-E19 (Behar et al., 1996, 1998, 2000).

\section{GABAergic-signaling components emerge in parallel with GABA receptors}

We examined the cellular distributions of other putative GABAergic-signaling components emerging during neuronal lineage progression including the expression of two GABAsynthesizing enzymes $\left(\mathrm{GAD}_{65}\right.$ and $\left.\mathrm{GAD}_{67}\right)$ and GABA (Fig. 3). Approximately $55-60 \%$ of the $\mathrm{DN}$ precursors were either $\mathrm{GAD}_{65}{ }^{+}$or $\mathrm{GAD}_{67}{ }^{+}$(Fig. $3 A 2, B 2$ ), whereas $<10 \%$ of SP-A2B5 neuroglial progenitors were immunopositive for either GAD (Fig. $3 A 1, A 2, B 1, B 2)$. Approximately $75-90 \%$ of the SP-TnTx ${ }^{10}$ neuronal progenitors were either $\mathrm{GAD}_{65}{ }^{+}$or $\mathrm{GAD}_{67}{ }^{+}$, making it likely that both enzymes were coexpressed in these cells. A minority of DP-TnTx ${ }^{\text {lo }}$ progenitors and DP-TnTx ${ }^{\text {hi }}$ neurons were $\mathrm{GAD}_{65}{ }^{+}$ $\left(\sim 30\right.$ and $\sim 35 \%$, respectively) or $\mathrm{GAD}_{67}{ }^{+}(\sim 18$ and $\sim 15 \%$, respectively), whereas the majority of SP-TnTx ${ }^{\text {hi }}$ neurons were either $\mathrm{GAD}_{65}{ }^{+}(\sim 80 \%)$ or $\mathrm{GAD}_{67}{ }^{+}(\sim 65 \%)$. GABA was primarily confined to neural precursors $(\sim 55 \%)$, SP-TnTx ${ }^{\text {lo }}$ neuronal progenitors $(\sim 75 \%)$, and differentiating SP-TnTx ${ }^{\text {hi }}$ neurons ( $\sim 95 \%)$, while being almost completely absent among SP-A2B5 cells (Fig. 3C1,C2). These results indicate that all of the components necessary to generate autocrine and paracrine GABAergic signals at GABA receptors are expressed during neuronal lineage progression, particularly in SP-TnTx neurons (see below).

\section{GABA release is dependent on $\mathrm{Ca}^{2+}$ entry via L-type $\mathrm{Ca}^{2+}$ channels}

The emergence of GABAergic neurons in the developing neocortex prompted us to investigate the possible mechanisms of GABA release from these cells. By using cell dissociation and TnTx/A2B5-labeling in conjunction with forward angle light scatter characteristics, a flow-cytometric property related to particle size (Fig. 4A), we examined the GABA immunoreactivity from cellular and subcellular compartments after treatment with different pharmacological conditions. Subcellular elements expressed the same pattern of TnTx and A2B5 labeling that was expressed by cell bodies with a significant percentage exhibiting 
A Cellular and Subcellular Elements

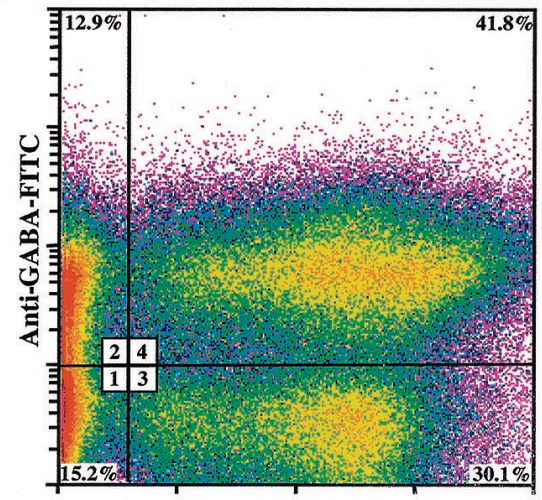

Forward Angle Light Scatter (channels)

C

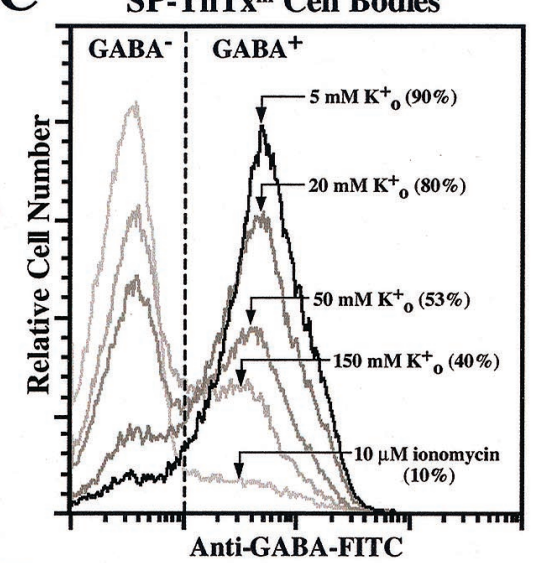

E

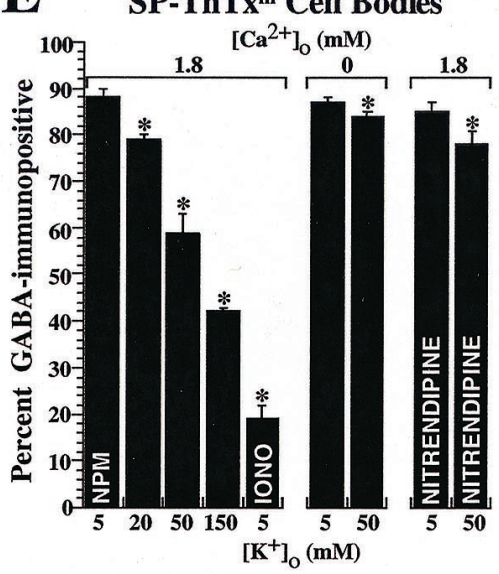

B

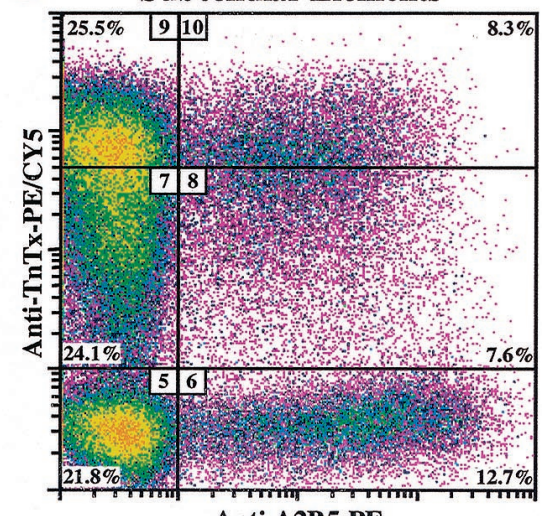

Anti-A2B5-PE

D

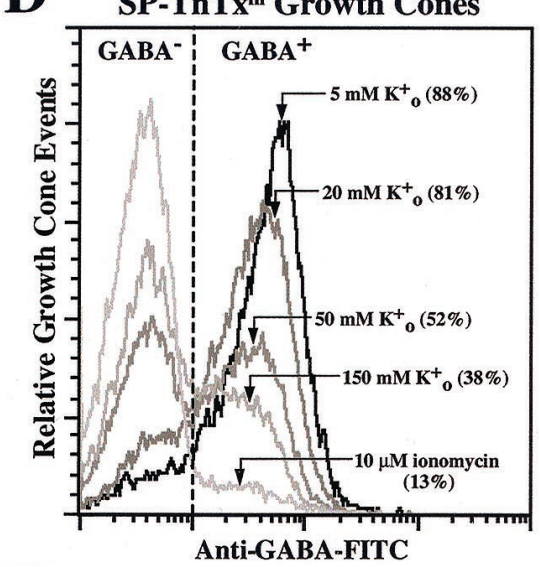

F

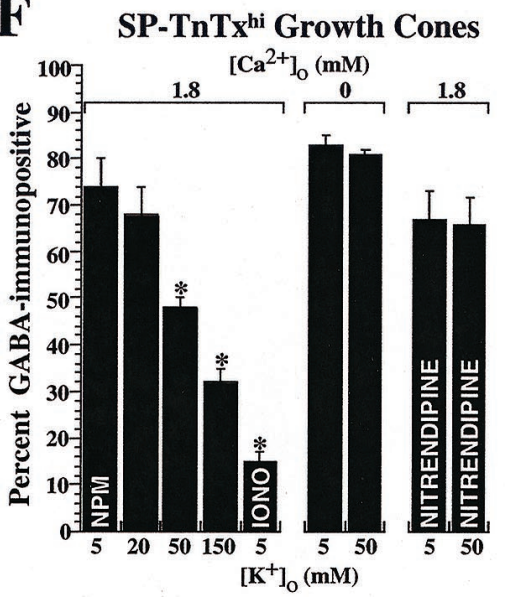

Figure 4. GABA release is modulated via activation of voltage-dependent $\mathrm{Ca}^{2+}$ channels. TnTx/A2B5-labeled neocortical dissociates were exposed to pharmacological conditions to induce GABA release and then fixed in PF, immunostained with anti-GABA antibody, and analyzed by flow cytometry for GABA-immunoreactive cellular and subcellular elements. $A$, The pseudocolored dot density plot shows the GABA immunoreactivity under control conditions (dissociates suspended in NPM) as a function of forward angle light scatter (FALS), a flowcytometric property related to particle size. As outlined by the crosshairs, the data were quantified in relative percentages of $\mathrm{GABA}^{-}$(region 1) and $\mathrm{GABA}^{+}$(region 2) subcellular elements with low FALS, in addition to $\mathrm{GABA}^{-}$(region 3) and $\mathrm{GABA}^{+}$(region 4 ) cell bodies with high FALS. $B$, Logical electronic gating on the subcellular elements $(A$; regions 1,2$)$ revealed the TnTx/ A2B5-labeling patterns and intensities (regions 5-10), which mirrored those characteristic of the six corresponding subpopulations of cortical cell bodies (Fig. 1). $C, D$, The frequency histogram plots under control $(5 \mathrm{~mm}$ $\mathrm{K}^{+}{ }_{\mathrm{o}}$ ) and experimental conditions illustrate the percentage of $\mathrm{GABA}^{+}$cell bodies $(C)$ and subcellular elements (putative growth cones; $D$ ) with TnTx/A2B5 immunophenotype that matched that of SP-TnTx ${ }^{\text {hi }}$ neurons. $E, F$, Dissociates were exposed for $15 \mathrm{~min}$ to increasing $\left[\mathrm{K}^{+}\right]_{\mathrm{o}}$ and to ionomycin $(I O N O)$, with or without $\mathrm{Ca}^{2+}$ in the recording medium, or to $10 \mu \mathrm{M}$ nitrendipine before addition of $\mathrm{K}^{+}$. Increasing $\mathrm{K}^{+}$leads to decreasing percentages of GABA-immunopositive cell bodies $(E)$ and growth cones $(F)$ of SP-TnTx ${ }^{\text {hi }}$ neurons, which become GABA-immunonegative, indicating complete GABA release from these compartments. Elevated $\mathrm{K}^{+}{ }_{\mathrm{o}}$ also produces a decrease in the modal fluorescence intensities (depicted by arrows; $C, D$ ) of the remaining $\mathrm{GABA}^{+}$cells and growth cones by $\sim 50 \%$, indicating fractional GABA release from these subpopulations. Ionomycin eliminates the immunodetectable GABA from $\sim 90 \%$ of SP-TnTx ${ }^{\text {hi }}$ cells and growth cones. The effects of $\mathrm{K}^{+}$and ionomycin on GABA release are neutralized when dissociates are resuspended in $\mathrm{Ca}^{2+}$-free saline, whereas the effects of $50 \mathrm{mM} \mathrm{K}^{+}$are blocked by nitrendipine. The bar graphs represent the percentage of GABA-immunopositive cells and growth cones (means \pm SEM) from three independent experiments. Asterisks depict statistically significant differences $(p<0.05$ or less) between experimental and resting $(N P M)$ conditions for each corresponding population. the same high level of TnTx-labeling intensity found with SP$\mathrm{TnTx}^{\text {hi }}$ neurons (Fig. 4B), suggesting that these elements represented sheared-off processes or growth cones from these cells. These data are supported by previous observations, which showed that TnTx labels the surface of embryonic cortical neurons quite uniformly (Maric et al., 2000b) and that $\mathrm{TnTx}^{+} \mathrm{GABA}^{+}$growth cones are readily detected in short-term cultures of embryonic neurons (Vautrin et al., 2000). To test GABA release, TnTx/ A2B5-labeled neocortical dissociates were treated for $15 \mathrm{~min}$ with increasing $\left[\mathrm{K}^{+}\right]_{\mathrm{o}}$ to depolarize cells or ionomycin to elevate intracellular $\mathrm{Ca}^{2+}$. The cells and subcellular elements were then spun down, fixed in $4 \% \mathrm{PF}$, and processed for GABA immunostaining, and the resulting immunoreactivity was quantified by flow cytometry. Under control conditions in NPM, 90\% of both SP-TnTx ${ }^{\text {hi }}$ cell bodies and subcellular elements (putative growth cones) were GABA immunoreactive (Fig. $4 C, D$ ). The percentages of GABA-immunopositive cells and growth cones decreased in parallel when $\mathrm{K}^{+}$o was elevated or ionomycin was added in NPM during the $15 \mathrm{~min}$ incubation (Fig. 4C,D). Exposure to ionomycin led to an $\sim 90 \%$ decrease in GABA-immunopositive cell bodies and growth cones, demonstrating that most of the immunodetectable GABA was labile (Fig. 4C,D). Furthermore, the released GABA was not adherent to or taken up by other cells because decreases were also detected in the percentages of $\mathrm{GABA}^{+}$cell bodies at earlier stages of lineage progression, whereas $\mathrm{GABA}^{-}$cells did not become $\mathrm{GABA}^{+}$(D. Maric and 
J. L. Barker, unpublished observations). $\mathrm{GABA}^{+} \mathrm{SP}^{-T_{n} T x^{\mathrm{lo}}}$ neuronal progenitors were less sensitive to $\mathrm{K}^{+}{ }_{\mathrm{o}}$-induced release, whereas $\mathrm{GABA}^{+} \mathrm{TnTx}^{-} \mathrm{A} 2 \mathrm{~B}^{-}{ }^{-}$neural precursors were the least sensitive and did not respond to $20 \mathrm{~mm} \mathrm{KCl}$ (data not shown). However, ionomycin released $\sim 90 \%$ of the immunodetectable GABA in these subpopulations, indicating that the GABA emergent in the earlier stages of lineage progression was also labile.

The $\mathrm{Ca}^{2+}$ dependency of evoked GABA release was evaluated by resuspending cells in $\mathrm{Ca}^{2+}$ o-free saline and then exposing them to elevated $\mathrm{K}^{+}{ }_{\mathrm{o}}$ or ionomycin. Resuspension in $\mathrm{Ca}^{2+}{ }_{\mathrm{o}}$-free saline did not affect the percentages of $\mathrm{GABA}^{+} \mathrm{SP}-\mathrm{TnT} \mathrm{x}^{\mathrm{hi}}$ cell bodies and growth cones but completely eliminated the changes induced by elevated $\mathrm{K}^{+}$o (Fig. 4E,F) and ionomycin (data not shown). These results demonstrate that $\mathrm{Ca}^{2+}$ entry is necessary to release immunodetectable GABA and that intracellular $\mathrm{Ca}^{2+}$ release, which occurs in these cells in $\mathrm{Ca}^{2+}$-free saline when exposed to ionomycin (Maric et al., 2000a), is not effective.

We also studied the possible role of voltage-dependent L-type $\mathrm{Ca}^{2+}$ channels in $\mathrm{Ca}^{2+}$-dependent GABA release, because these channels become functionally expressed during neuronal lineage progression (Maric et al., 2000a). Nitrendipine, which blocks L-type $\mathrm{Ca}^{2+}$ channels, antagonized the GABA release by elevated $\mathrm{K}^{+}{ }_{\mathrm{o}}$ in both SP-TnTx ${ }^{\text {hi }}$ cell bodies and growth cones (Fig. $4 E, F)$, thus identifying voltage-dependent L-type $\mathrm{Ca}^{2+}$ channels as the primary pathway for $\mathrm{Ca}^{2+}$ entry triggering GABA release. Collectively, these results demonstrate that most of the GABA in cell bodies and growth cones of differentiating cortical neurons is labile and can be released via $\mathrm{Ca}^{2+}$ entry through $\mathrm{L}$-type $\mathrm{Ca}^{2+}$ channels.

\section{Functional responses to GABA increase during neuronal differentiation}

To investigate the appearance and distribution of functional GABAergic signals during cortical cell development, CP/SP and VZ/SVZ dissociates were immunolabeled with TnTx/A2B5 and stained with potentiometric or calcium-sensitive physiological indicator dyes, before pharmacological experiments targeting $\mathrm{GABA}_{\mathrm{A}}$ and $\mathrm{GABA}_{\mathrm{B}}$ receptors were performed. Because differentiating neocortical neurons became progressively GABAergic (Fig. 3) and endogenous GABA signaling increasingly contributed to their baseline properties (see Figs. 6-9), we have empirically supplemented the NPM with BSA, which effectively reduced the contribution of endogenous GABA signaling (see Fig. 9A), before testing the effects of exogenously applied GABA or GABAmimetic agonists or antagonists. As expected from the distribution of GABA receptor subunits among phenotyped subpopulations (Fig. 1), both membrane potential and $\mathrm{Ca}^{2+}{ }_{\mathrm{c}}$ responses to exogenous GABA were primarily confined to cells undergoing neuronal differentiation (Fig. 5). GABA depolarized or elevated $\mathrm{Ca}^{2+}{ }_{\mathrm{c}}$ in only a fraction $(10-15 \%)$ of the $\mathrm{TnTx}^{-} \mathrm{A} 2 \mathrm{~B} 5^{-}$neural precursors and SP-A2B5 neuroglial progenitors from the VZ/SVZ (Fig. $5 A 1, A 2, B 1, B 2)$. GABA responses increased in DP-TnTx ${ }^{\text {lo }}$ neuronal progenitors, $25 \%$ of which depolarized (Fig. $5 A 2$ ), but none elevated $\mathrm{Ca}^{2+}{ }_{\mathrm{c}}$ (Fig. 5B2). In contrast, $\sim 50 \%$ of the SP-TnTx ${ }^{1 \mathrm{o}}$ neuronal progenitors depolarized (Fig. 5A2) and $\sim 25 \%$ elevated $\mathrm{Ca}^{2+}$ c (Fig. 5B2) after exposure to GABA. Similarly, GABA depolarized $\sim 60 \%$ of the DP-TnTx ${ }^{\text {hi }}$ neurons (Fig. 5A2), while elevating $\mathrm{Ca}^{2+}{ }_{\mathrm{c}}$ in only $\sim 20 \%$ (Fig. 5B2). The most responsive population was detected among SP-TnTx ${ }^{\text {hi }}$ neurons from the $\mathrm{CP} /$ SP, $\sim 90 \%$ of which were depolarized by GABA (Fig. 5A1, $A 2)$ and $\sim 55 \%$ of which responded with elevated $\mathrm{Ca}^{2+}{ }_{\mathrm{c}}$ (Fig. 5B1,B2).

Virtually all of the depolarizing responses to GABA were mimicked by the $\mathrm{GABA}_{\mathrm{A}}$ receptor agonist muscimol and blocked by either bicuculline or picrotoxin (data not shown; but see Figs. $6-9$ ), indicating a direct involvement of $\mathrm{GABA}_{\mathrm{A}}$ receptor $/ \mathrm{Cl}^{-}$ channels in the phenomenology. Elevation in $\mathrm{Ca}^{2+}{ }_{\mathrm{c}}$ levels induced by GABA was for the most part antagonized by bicuculline, picrotoxin, and nitrendipine (data not shown; but see Fig. 9), suggesting a mechanism involving $\mathrm{Ca}^{2+}$ entry via L-type voltagedependent $\mathrm{Ca}^{2+}$ channels, which were putatively activated by GABA-induced depolarization. Baclofen did not produce detectable changes in either membrane potential or $\mathrm{Ca}^{2+}{ }_{\mathrm{c}}$ (data not shown), implying either that the function of $\mathrm{GABA}_{\mathrm{B}}$ receptor/ $\mathrm{Ca}^{2+}$ channels might have been compromised during acute cell preparation or that the activation of these receptors nominally contributes to membrane potential or $\mathrm{Ca}^{2+}{ }_{c}$ at this stage of cortical neuron development. Relatively modest contributions of $\mathrm{GABA}_{\mathrm{B}}$ receptor/ $\mathrm{Ca}^{2+}$ channels to $\mathrm{Ca}^{2+}{ }_{\mathrm{c}}$ levels were indeed shown in cell cultures of migrating and differentiating cortical neurons after recovery from dissociation (see Behar et al., 1996) (see Fig. 9B).

To test the potency of muscimol at $\mathrm{GABA}_{\mathrm{A}}$ receptors, the cells were resuspended in low $\mathrm{Cl}^{-}$-containing saline to maximize detection of $\mathrm{Cl}^{-}$-dependent depolarizing responses. Under these conditions, muscimol depolarized more cells in each subpopulation studied (Fig. 5C1, C2) than GABA (or muscimol) did in the saline-containing normal $\mathrm{Cl}^{-}{ }_{\text {o }}$ (Fig. $5 A 2$ ), with most cells depolarizing to $-15 \mathrm{mV}$ rather than to $-45 \mathrm{mV}$ (data not shown). These optimized experimental conditions show that all of the depolarizing responses are $\mathrm{Cl}^{-}$ion dependent and that some cells depolarized by GABA in normal saline likely went undetected with this strategy. Systematic dose-response studies under these optimized conditions showed that $\geq 10 \mu \mathrm{M}$ concentrations of muscimol were asymptotic in depolarizing up to $46 \%$ of $\mathrm{TnTx}^{-} \mathrm{A} 2 \mathrm{~B} 5{ }^{-}$neural precursor cells and up to $35 \%$ of DP$\mathrm{TnTx}^{\text {lo }}$ neuronal progenitors, whereas $\leq 5 \mu \mathrm{M}$ concentrations were asymptotic in depolarizing the great majority of cells in all other neuronal subpopulations. The $\mathrm{EC}_{50}$ values decreased from micromolar to submicromolar as TnTx labeling intensified in differentiating neurons, whereas Hill coefficients remained relatively constant ranging from 1.4 to 1.8 (Fig. 5C2). The increase in agonist potency may be related to the evolving $\mathrm{GABA}_{\mathrm{A}}$ receptor subunit compositions and receptor densities.

\section{Electrophysiology of $\mathrm{GABA}_{\mathrm{A}}$ autoreceptor $/ \mathrm{Cl}^{-}$channel activity in CP/SP neurons}

The concerted expression of GABAergic-signaling components and the presence of releasable GABA at the level of cell bodies and growth cones of differentiating cortical neurons led us to investigate the effects of endogenous GABA on membrane properties of these cells. We used patch-clamp techniques to optimize the recording of $\mathrm{Cl}^{-}$-dependent currents in acutely cultured $\mathrm{CP} / \mathrm{SP}$ neurons under unperfused and superfused conditions. Without perfusion, all differentiating neurons $(n=8)$, which were recorded in the whole-cell mode and clamped at negative potentials, exhibited fluctuating baseline current signals, which were reduced after diffusion of bicuculline into the unperfused bath (Fig. 6A1). Spectral analysis showed that the bicuculline-sensitive fluctuating baseline signal could be fitted by two Lorentzian terms, indicating two exponential distributions in the burst-length durations of the randomly activated $\mathrm{Cl}^{-}$channels (Fig. 6A3). Continuous superfusion of the recorded neurons with fresh saline rapidly eliminated most of the baseline current signal and associated fluctuations (Fig. 6, compare $B 1, A 1$ ), creating a steady DC 
A1

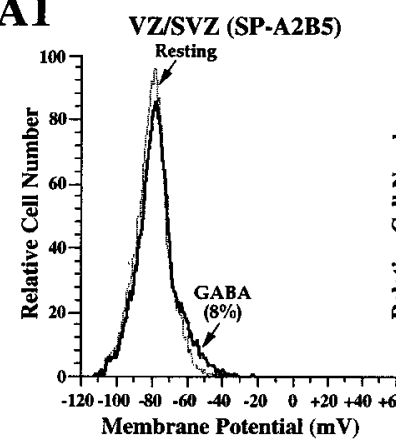

B1

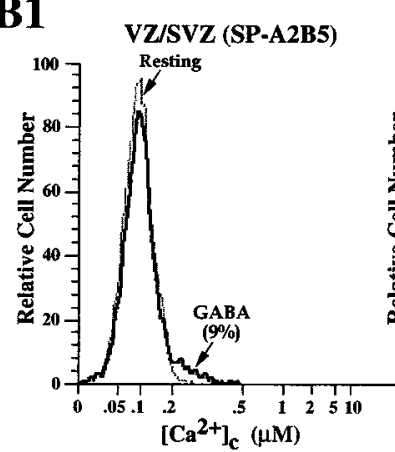

C1

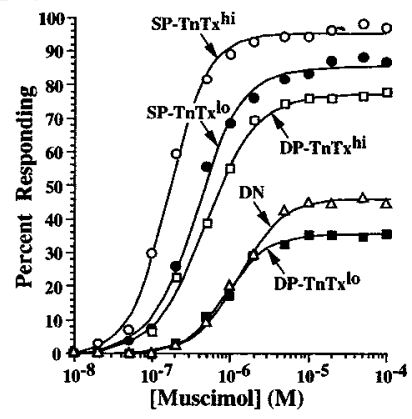

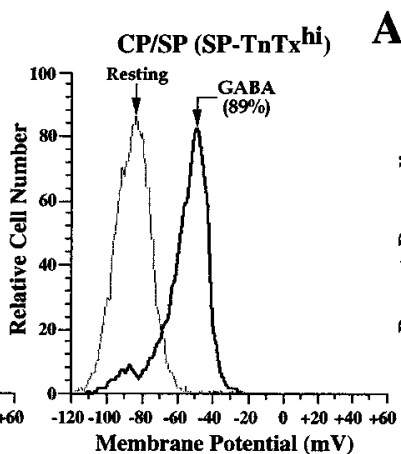

A2

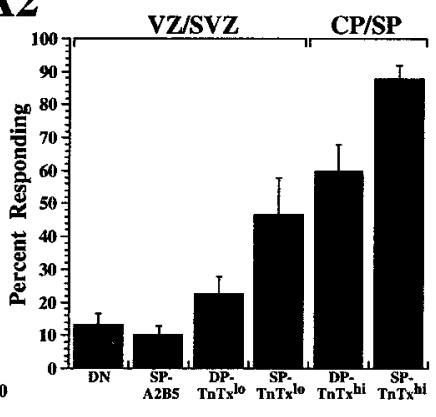

B2
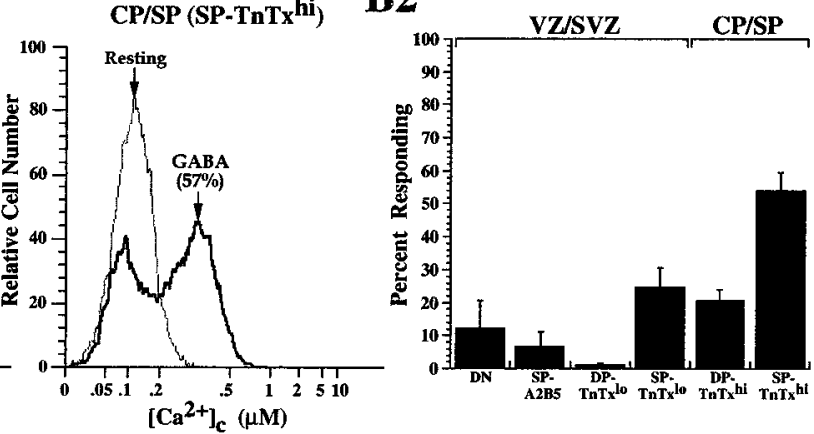

$\mathrm{C} 2$

\begin{tabular}{|c|c|c|c|c|}
\hline $\begin{array}{c}\text { Cell } \\
\text { Phenotype }\end{array}$ & $\begin{array}{c}\text { Maximum } \\
\text { Responding }\end{array}$ & $\mathrm{EC}_{50}$ & $\begin{array}{c}\text { Hill } \\
\text { Coefficient } \\
\end{array}$ & $\mathbf{R}$ \\
\hline SP-TnT & $95 \%$ & $160 \mathrm{nM}$ & 1.8 & 0.99 \\
\hline SP-TnTx lo & $85 \%$ & $360 \mathrm{nM}$ & 1.5 & 0.99 \\
\hline DP-TnTx ${ }^{h i}$ & $77 \%$ & $470 \mathrm{nM}$ & 1.4 & 0.99 \\
\hline DP-TnTx ${ }^{10}$ & $35 \%$ & $900 \mathrm{nM}$ & 1.6 & 0.99 \\
\hline DN & $46 \%$ & $1.2 \mu \mathrm{M}$ & 1.6 & 0.99 \\
\hline
\end{tabular}

Figure 5. Distribution of pharmacological responses to GABA during neuronal lineage progression parallels the expression of $\mathrm{GABA}_{\mathrm{A}}$ receptor subunits. Cells dissociated from the $\mathrm{CP} / \mathrm{SP}$ and $\mathrm{VZ} / \mathrm{SVZ}$ were labeled with $\mathrm{TnTx} /$ A2B5 and stained with oxonol or fluo-3. Changes in membrane potential and $\mathrm{Ca}^{2+}{ }_{\mathrm{c}}$ to exogenous application of GABA or GABA mimetics were quantified in phenotyped subpopulations using flow cytometry. Before the pharmacological application of varying concentrations $\left(10^{-8}-10^{-4} \mathrm{M}\right)$ of GABA, muscimol, or baclofen, the cells were first resuspended in NPM/BSA to reduce the contribution of endogenous GABA signaling (Fig. 9A). A1, B1, Typical resting oxonol and fluo-3 fluorescence signal distributions from $\sim 10,000$ SP-A2B5 neuroglial progenitors from the VZ/SVZ and SP-TnTx ${ }^{\text {hi }}$ differentiating neurons from the $\mathrm{CP} / \mathrm{SP}$ (thin-line frequency histograms) and their corresponding distributions after peak changes in membrane potential and $\mathrm{Ca}^{2+}{ }_{\mathrm{c}}$ recorded within $2 \mathrm{~min}$ after application of $10 \mu \mathrm{M}$ GABA (thick-line frequency histograms) are illustrated. The raw data illustrate the highly contrasting results, with the percentage of responding cells shown in parentheses. A2, B2, The bar graphs represent the percentage of total cells (means \pm SEM from 3 independent experiments) depolarizing or increasing $\mathrm{Ca}^{2+}$ in response to asymptotic concentrations of GABA $(\geq 10 \mu \mathrm{M})$ in the six subpopulations studied. Few DN neural precursor cells or SP-A2B5 neuroglial progenitors respond to GABA. In contrast, GABA depolarizes the great majority of SP$\mathrm{TnTx}^{\text {hi }}$ neurons from their modal resting potential of -80 to $-45 \mathrm{mV}$ at the peak response (A1). The proportion of cells exhibiting depolarizing responses to GABA increases progressively among cells undergoing neuronal lineage progression (A2). Both SP-TnTx ${ }^{+}$subpopulations contain more responding neurons than do the DP-TnTx ${ }^{+}$counterparts. Few SP-A2B5 progenitors or DN precursor cells increase $\mathrm{Ca}^{2+}{ }_{\mathrm{c}}$ in response to $\operatorname{GABA}(B 1, B 2)$, whereas more than half the SP-TnTx ${ }^{\text {hi }}$ neurons respond, with most peaking at $\sim 400 \mathrm{nM} \mathrm{Ca}^{2+}{ }_{\mathrm{c}}(B 1)$. Cells expressing GABA-induced Ca ${ }^{2+}{ }_{\mathrm{c}}$ responses are primarily confined

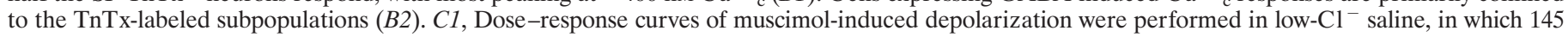
$\mathrm{mm} \mathrm{NaCl}$ was substituted with an equimolar concentration of $\mathrm{Na}$ isethionate (Sigma), to amplify $\mathrm{Cl}^{-}$-dependent depolarization. The results show that consistently more cells depolarize under these conditions compared with those depolarized by GABA in normal $\mathrm{Cl}^{-}$-containing saline ( $A 2$ ). $C 2$, Pharmacological properties of $\mathrm{GABA}_{\mathrm{A}}$ receptors change systematically during neuronal lineage development, with $\mathrm{EC}_{50}$ values progressively decreasing as TnTx labeling intensifies. SP-TnTx ${ }^{10}$ and SP-TnTx ${ }^{\text {hi }}$ subpopulations contain the greatest number of responding cells and exhibit the lowest EC $\mathrm{C}_{50}$ values. Hill coefficients remain relatively constant during neuronal differentiation.

level with spontaneous intermittent openings of $\mathrm{Cl}^{-}$channels whose frequency was not sufficient to generate a summating current signal.

After superfusion, application of micromolar GABA typically evoked an inward $\mathrm{Cl}^{-}$current response superimposed with random fluctuations in all recorded neurons, which, after spectral analysis, involved the same pair of exponentially distributed burst-length durations found with the endogenous baseline signal recorded in the absence of superfusion (Fig. 6, compare B2,A3).

All of the continuously superfused CP/SP neurons recorded in a whole-cell mode exhibited a residual level of $\mathrm{Cl}^{-}$channel activity. This activity was rapidly and reversibly eliminated by bicuculline (Fig. $7 A$ ) and reversed polarity at $0 \mathrm{mV}\left(\sim E_{\mathrm{Cl}}\right)$ (data not shown). Quantitative analyses revealed single $\mathrm{Cl}^{-}$channel levels of activity in all superfused neurons (Fig. $7 B$ ) with the unitary properties of GABA-activated $\mathrm{Cl}^{-}$channels. The residual $\mathrm{Cl}^{-}$channel activity most likely reflected autocrine activation of $\mathrm{GABA}_{\mathrm{A}}$ autoreceptor/Cl- ${ }^{-}$channels by $\mathrm{GABA}$ at the under- surface of the neuron, which was not as accessible to superfusion as the upper surface. The bicuculline sensitivity of both the endogenous baseline macroscopic current signal and the microscopic $\mathrm{Cl}^{-}$channel activity persisting during superfusion, together with the close similarities in the burst-length durations estimated for the summating $\mathrm{Cl}^{-}$channel activity composing the baseline and GABA-activated macroscopic currents, strongly suggests that the baseline signal is dominated by GABA-induced activation of $\mathrm{GABA}_{\mathrm{A}}$ autoreceptor $/ \mathrm{Cl}^{-}$channels, which evolves from a surface-accessible compartment.

\section{Autocrine GABAergic signaling tonically elevates $\mathrm{Ca}^{2+}$ c levels}

We also investigated the effects of endogenous GABA on potentiometric and $\mathrm{Ca}^{2+}$ signaling in differentiating cortical neurons using a noninvasive optical strategy. We used a dual video microscopic-imaging technique to record simultaneously membrane potential and $\mathrm{Ca}^{2+}{ }_{\mathrm{c}}$ levels of acutely cultured $\mathrm{CP} / \mathrm{SP}$ neu- 
Figure 6. Autocrine activation of $\mathrm{GABA}_{\mathrm{A}}$ receptor/ $\mathrm{Cl}^{-}$channels by GABA dominates baseline conductance in differentiating GABAergic neurons. Whole-cell patch-clamp recording with a $\mathrm{Cl}^{-}$-filled pipette was used to maintain membrane potential at $-80 \mathrm{mV}$ in a representative $\mathrm{CP} / \mathrm{SP}$ neuron, which had been cultured for $24 \mathrm{hr}$ and was initially recorded in an unperfused plate. $A 1$, The macroscopic baseline current signal exhibits random microscopic fluctuations until the recorded neuron is exposed to bicuculline, which depresses most of the ongoing $\mathrm{Cl}^{-}$channel activity and shifts the average current to a less negative value. $A 2$, Histograms of signal amplitude accumulated over time reveal symmetrical distributions before and after bicuculline with the baseline current averaging approximately -8 pA (equivalent to $\sim 100 \mathrm{pS}$ conductance). The dotted lines represent Gaussian fits to the baseline and signal distribution. $A 3$, Spectral analysis of the bicuculline-sensitive current fluctuations reveals two exponentially distributed burst-length durations ( $\sim 3$ and $\sim 100 \mathrm{msec})$ in $\mathrm{Cl}^{-}$channel activity, with the latter accounting for $\sim 80 \%$ of the power in the signal. B1, Superfusion of the plate eliminates the fluctuating baseline current signal, leaving random, spontaneous $\mathrm{Cl}^{-}$channel openings that do not summate. Exogenous application of $3 \mu \mathrm{M}$ GABA evokes a sustained inward (negative) current response of approximately $-30 \mathrm{pA}$ superimposed with fluctuations. $B 2$, Spectral analysis reveals two exponentially distributed burst-length durations with values that are virtually identical to those calculated from the baseline signal.
A1 Baseline signal $50 \mu \mathrm{M}$ Bicuculline
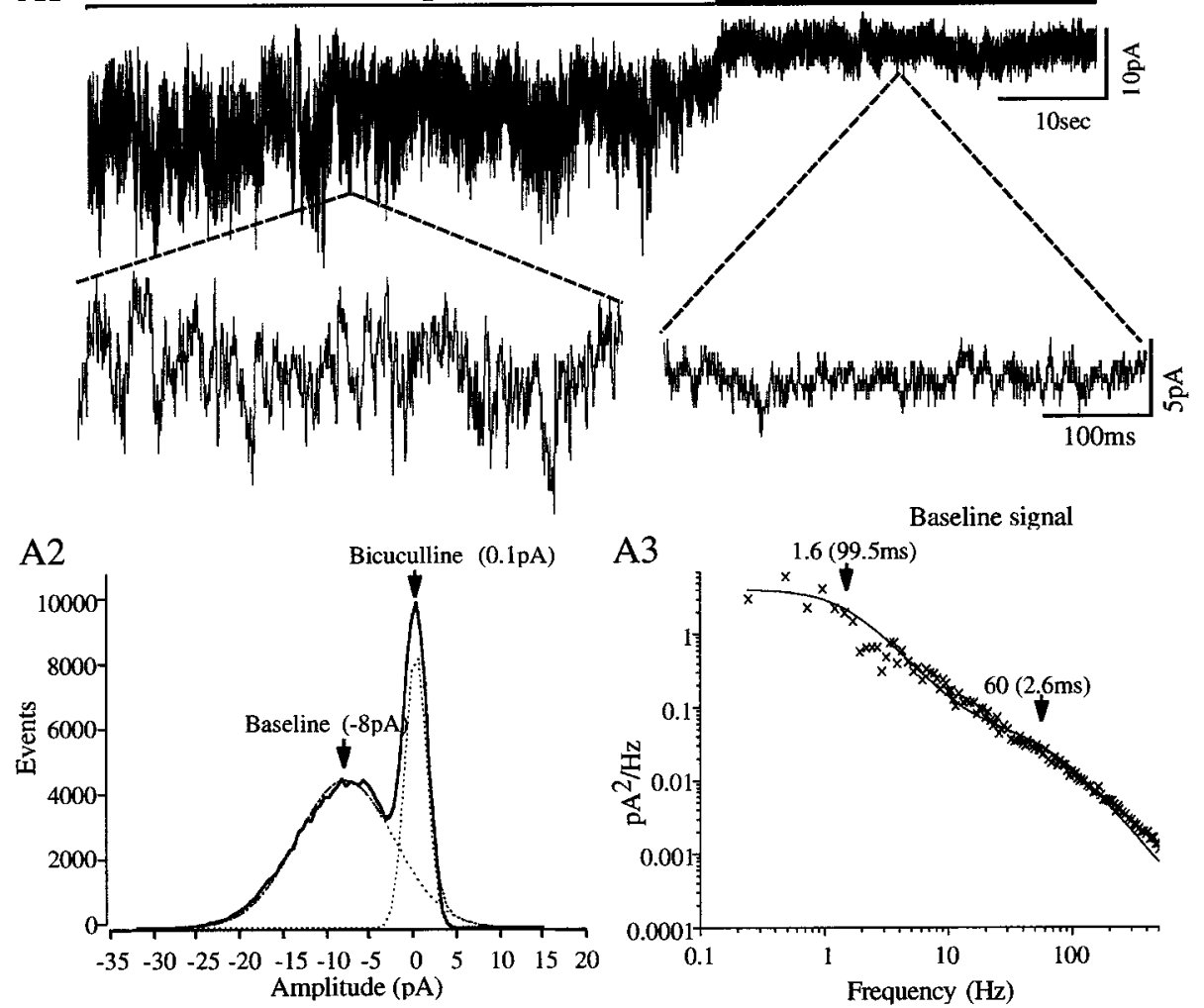

B1 $3 \mu \mathrm{M} \mathrm{GABA}$

B2

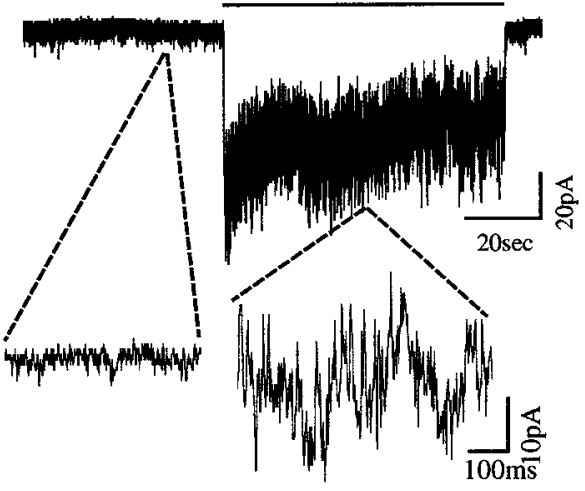

rons. After imaging, the neurons were immunoidentified with TnTx and A2B5 labeling. The analysis was focused on neurons with the SP-TnTx phenotype because most of them were GABAergic at the beginning of culture, although DP-TnTx neurons increasingly became GABAergic after $24 \mathrm{hr}$ of culture (data not shown). The great majority $(>80 \% ; n=32)$ of SP-TnTx ${ }^{\text {hi }}$ neurons, which were continuously superfused with NPM, exhibited baseline membrane potentials of approximately $-50 \mathrm{mV}$ (Fig. 8, top). Bicuculline rapidly and reversibly hyperpolarized these cells from $-50 \mathrm{mV}$ to near $-80 \mathrm{mV}$. In addition, bicuculline rapidly and reversibly depressed baseline $\mathrm{Ca}^{2+}{ }_{\mathrm{c}}$ levels in those SP-TnTx ${ }^{\text {hi }}$ neurons that coexpressed significant levels of voltagedependent $\mathrm{Ca}^{2+}$ entry, which was identified by stepwise depolarization with elevated $\mathrm{KCl}$ (Fig. 8, bottom). The time courses in potential and $\mathrm{Ca}^{2+}{ }_{\mathrm{c}}$ changes were nearly superimposable despite the disparities in the response times of the two dyes, indicating that the two parameters were closely linked. The much slower response time of the potentiometric dye $(\sim 60 \mathrm{sec})$ compared with that of fura-2 $(\sim 1 \mathrm{sec})$ suggests that the rate of hyperpolarization induced by bicuculline governed the rate of decrease in $\mathrm{Ca}^{2+}{ }_{\mathrm{c}}$ level. Putatively less-differentiated CP/SP neurons with the SP$\mathrm{TnTx}^{1 \mathrm{o}}$ phenotype, which constituted $\leq 15 \%$ of the cultured cells, exhibited relatively low baseline $\mathrm{Ca}^{2+}{ }_{\mathrm{c}}$ levels $(<100 \mathrm{~nm})$ and were insensitive to the hyperpolarizing effects of bicuculline. In addition, these neurons did not respond to stepwise increases in $\left[\mathrm{K}^{+}\right]_{\mathrm{o}}$ despite being depolarized to the same membrane potentials as SP-TnTx ${ }^{\text {hi }}$ neurons with bicuculline-sensitive baseline $\mathrm{Ca}^{2+}{ }_{\mathrm{c}}$ levels (Fig. 8). Interestingly, most SP-TnTx ${ }^{\text {hi }}$ neurons that had differentiated in culture for $24 \mathrm{hr}$ were depolarized by $20 \mathrm{~mm}$ $\mathrm{KCl}$ to approximately the same potential and generated approximately the same baseline $\mathrm{Ca}^{2+}{ }_{\mathrm{c}}$ level that was recorded in $5 \mathrm{~mm}$ $\mathrm{K}^{+}$. Thus, the autocrine GABAergic signaling at $\mathrm{GABA}_{\mathrm{A}}$ receptor/ $\mathrm{Cl}^{-}$channels dominated the baseline properties of these cells over the 5-20 $\mathrm{mm}$ range of $\left[\mathrm{K}^{+}\right]_{\mathrm{o}}$.

To investigate the possible mechanisms underlying autocrine GABAergic regulation of baseline $\mathrm{Ca}^{2+}{ }_{\mathrm{c}}$ in SP-TnTx ${ }^{\text {hi }}$ neurons, 


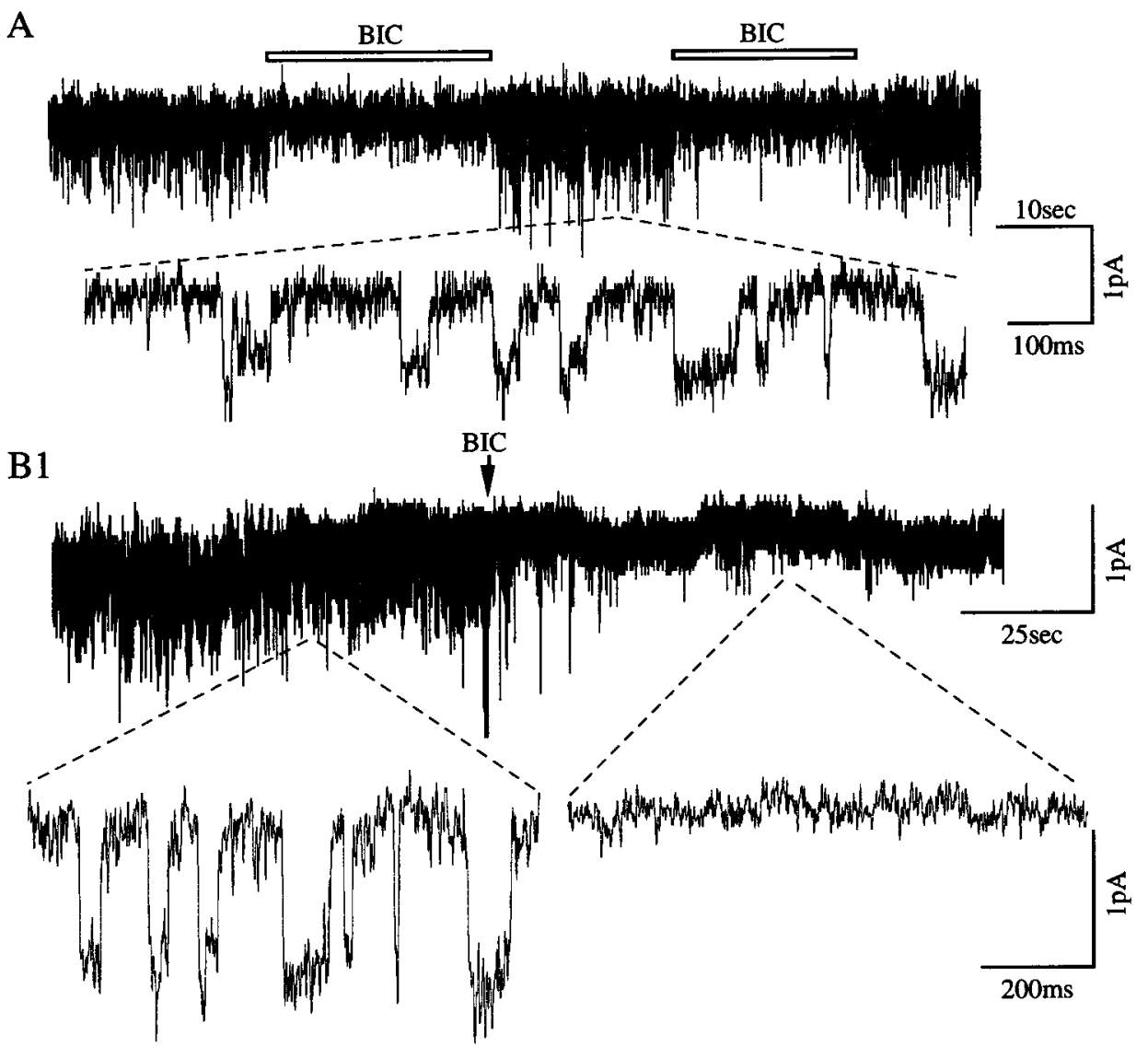

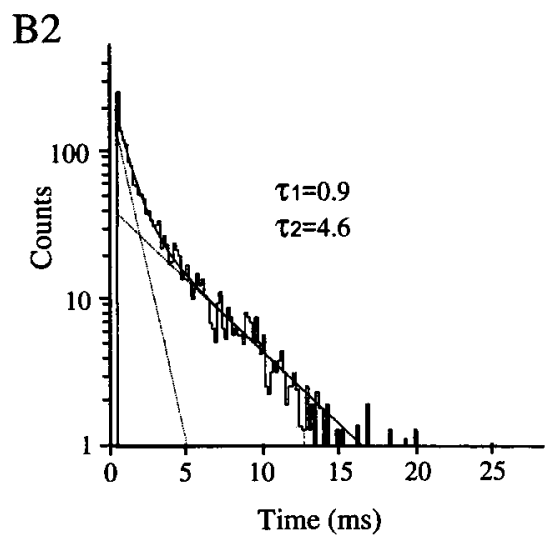

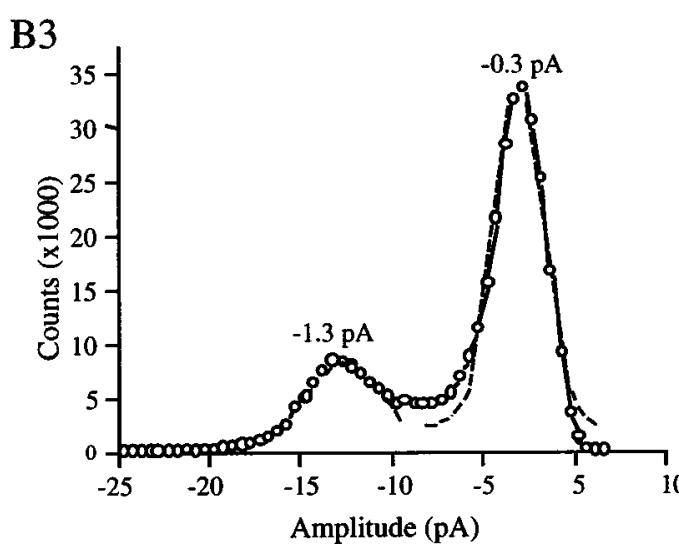

Figure 7. Spontaneous $\mathrm{GABA}_{\mathrm{A}}$ autoreceptor/ $\mathrm{Cl}^{-}$channel activity recorded in the whole-cell mode in superfused CP/SP neurons. The neurons were cultured for $24 \mathrm{hr}$ and clamped in the whole-cell mode with $\mathrm{Cl}^{-}$-filled pipettes while being continuously superfused with fresh saline. A, Bicuculline (100 $\mu \mathrm{M}$; open horizontal bars) included in the superfusing saline rapidly and reversibly blocks the majority of $\mathrm{Cl}^{-}$channel openings (downward-going deflections in the top trace). The all-or-none activity is displayed at a faster time base in the bottom trace. B1, Bicuculline (arrow) blocks the spontaneous $\mathrm{Cl}^{-}$channel activity in another $\mathrm{CP} / \mathrm{SP}$ neuron. $B 2$, There are two exponential distributions in the open channel activities $\left(\tau_{1}, \sim 0.9 \mathrm{msec} ; \tau_{2}\right.$, $0 \sim 4.6 \mathrm{msec}$ ). $B 3$, The amplitude histogram of the channel activity is nearly symmetrical with a single well defined mode at $-1.3 \mathrm{pA}$. we performed pharmacological experiments targeting the contribution of endogenous GABA synthesis, $\mathrm{GABA}_{\mathrm{A}}$ and $\mathrm{GABA}_{\mathrm{B}}$ receptors, intracellular $\mathrm{Cl}^{-}$ion homeostasis, and voltagedependent $\mathrm{L}$-type $\mathrm{Ca}^{2+}$ channels. In addition, the accessibility of endogenous GABA was tested in the presence of albumin serum proteins (i.e., BSA), which purportedly act as natural carriers for a wide spectrum of signaling molecules in vivo. Superfusion with BSA closely mimicked the depressant effects of bicuculline and picrotoxin on $\mathrm{Ca}^{2+}$ c levels both in terms of time course of decrease and recovery and extent (Fig. $9 A$ ). Both phases could be approximated by monoexponential time courses, which were $\sim 2$ min for the decreasing phase and $\sim 1 \mathrm{~min}$ for recovery. In one representative experiment, $\mathrm{Ca}^{2+}{ }_{\mathrm{c}}$ levels in $30 \mathrm{SP}-\mathrm{TnTx}^{\mathrm{hi}}$ neurons averaged $97 \pm 4 \mathrm{nM}$ (mean \pm SEM) during superfusion before BSA, $52 \pm 4 \mathrm{~nm}$ after the effect of BSA had asymptoted, $99 \pm 6$ $\mathrm{nm}$ in recovery, $59 \pm 5 \mathrm{~nm}$ after bicuculline and picrotoxin, and $105 \pm 6 \mathrm{~nm}$ after another recovery. These results demonstrated the persistence and robustness of autocrine GABAergic signaling at $\mathrm{GABA}_{\mathrm{A}}$ receptor/ $\mathrm{Cl}^{-}$channels under continuous superfusion in saline. Previously, we reported that BSA stabilized the resting potentials of virtually all dissociated cortical cells and cultured $\mathrm{CP} / \mathrm{SP}$ neurons near or at the equilibrium potential for $\mathrm{K}^{+}$ions and lowered $\mathrm{Ca}^{2+}{ }_{\mathrm{c}}$ levels to $\sim 100 \mathrm{~nm}$ or less (Maric et al., 1998c, $2000 \mathrm{~b})$. Although the mechanisms of the effects of BSA are as yet unclear, it may be important physiologically during cortical development.

Superfusion with saclofen, a $\mathrm{GABA}_{\mathrm{B}}$ receptor antagonist, depressed baseline $\mathrm{Ca}^{2+}{ }_{\mathrm{c}}$ levels in $\sim 60 \%$ of $32 \mathrm{SP}-\mathrm{TnTx}^{\mathrm{hi}}$ neurons studied (Fig. 9B). However, this decrease in $\mathrm{Ca}^{2+}{ }_{\mathrm{c}}$ level was relatively modest $(19 \pm 3 \mathrm{nM} ; n=20)$ compared with the effects 
Figure 8. Autocrine GABAergic signaling at $\mathrm{GABA}_{\mathrm{A}}$ receptor $/ \mathrm{Cl}^{-}$channels polarizes $\mathrm{CP} / \mathrm{SP}$ neurons near $-50 \mathrm{mV}$ and sustains $\mathrm{Ca}^{2+}{ }_{c}$ levels in neurons with $\mathrm{K}^{+}$ dependent $\mathrm{Ca}^{2+}{ }_{\mathrm{c}}$ responses. Dual-imaging of oxonol and fura- 2 was used to study the membrane potential and $\mathrm{Ca}^{2+}{ }_{\mathrm{c}}$ levels of $\mathrm{CP} / \mathrm{SP}$ neurons cultured for $24 \mathrm{hr}$, which were immunolabeled with TnTx and A2B5 post hoc to discriminate between SP-TnTx and DP-TnTx phenotypes. The intensities of immunolabeling reactions were quantified from digitally captured images of TnTx and A2B5 fluorescence using NIH Image software. TnTx ${ }^{\text {lo }}$ and $\operatorname{TnTx} \mathrm{x}^{\mathrm{hi}}$ populations were discriminated by digitally thresholding the TnTx fluorescence at 50\% maximal intensity. The potentiometric (top) and $\mathrm{Ca}^{2+}$ (bottom) signals recorded simultaneously from two representative neurons of SP$\operatorname{TnTx}^{\text {lo }}$ (red traces) and SP-TnTx ${ }^{\text {hi }}$ (blue traces) phenotype were calibrated according to previously established protocols (Maric et al., 2000b). While being continuously superfused with NPM, both populations of neurons remain polarized near $-50 \mathrm{mV}$, and both are hyperpolarized in $100 \mu \mathrm{M} \mathrm{BIC}$ (solid horizontal bar) by $25-30 \mathrm{mV}$ in a reversible manner. Elevating $\left[\mathrm{K}^{+}\right]_{\mathrm{o}}$ (open horizontal bars) from 5 to $20 \mathrm{~mm}$ does not alter membrane potential, whereas 50 and 150 $\mathrm{mm}$ depolarize both neurons to approximately -30 and $\sim 0 \mathrm{mV}$, respectively. Simultaneous imaging of $\mathrm{Ca}^{2+}{ }_{\mathrm{c}}$ levels reveals multan $\mathrm{Ca}^{2+} \mathrm{c}$.

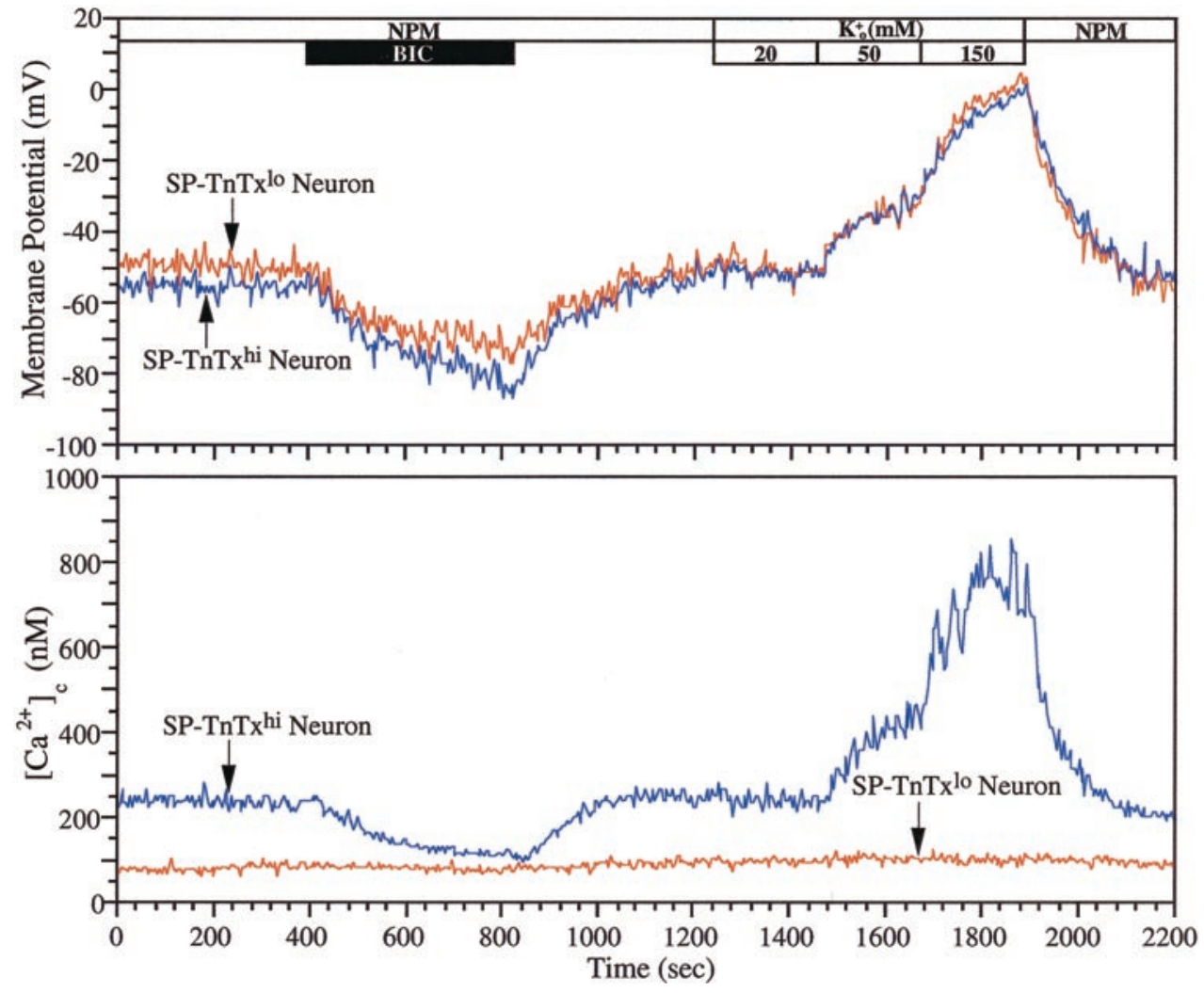

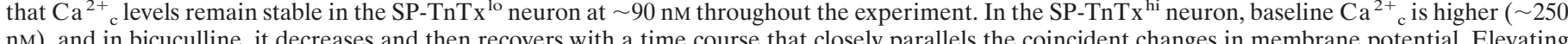
$\mathrm{nM}$ ), and in bicuculline, it decreases and then recovers with a time course that closely parallels the coincident changes in membrane potential. Elevating $\left[\mathrm{K}^{+}\right]_{\mathrm{o}}$ to $20 \mathrm{~mm}$ does not increase $\mathrm{Ca}^{2+}{ }_{\mathrm{c}}$, whereas 50 and $150 \mathrm{mM} \mathrm{K}^{+}{ }_{\mathrm{o}}$ increase $\mathrm{Ca}^{2+}{ }_{\mathrm{c}}$ to 450 and $800 \mathrm{~nm}$, respectively.

of antagonists at $\mathrm{GABA}_{\mathrm{A}}$ receptor $/ \mathrm{Cl}^{-}$channels, which decreased $\mathrm{Ca}^{2+}{ }_{\mathrm{c}}$ levels by $55 \pm 5 \mathrm{nM}$ in the same neurons. Superfusion of these neurons with 3-MPA, which blocks GAD-derived synthesis of GABA, decreased baseline $\mathrm{Ca}^{2+}{ }_{\mathrm{c}}$ levels to an extent similar to that of bicuculline/picrotoxin, when compared in the same experiment. For example, bicuculline/picrotoxin depressed $\mathrm{Ca}^{2+}{ }_{\mathrm{c}}$ levels in 37 neurons by $52 \pm 4 \mathrm{~nm}$, whereas 3-MPA decreased $\mathrm{Ca}^{2+}$ by $58 \pm 3 \mathrm{~nm}$ (Fig. 9B). However, the time course of the depressant effect of 3-MPA was delayed rather than immediate and gradual compared with that of either GABA receptor antagonists and, unlike them, not rapidly reversible. $\mathrm{Ca}^{2+}{ }_{\mathrm{c}}$ levels only partially recovered after $10-20 \mathrm{~min}$ of superfusion in saline free of 3-MPA. The depressant effects of 3-MPA on baseline $\mathrm{Ca}^{2+}{ }_{\mathrm{c}}$ did not interfere with the $\mathrm{Ca}^{2+}{ }_{\mathrm{c}}$ response evoked by exogenous GABA (Fig. 9B), indicating that its effects did not involve activation either of $\mathrm{GABA}_{\mathrm{A}}$ receptors by GABA or of the downstream components necessary for elevating $\mathrm{Ca}^{2+}{ }_{c}$. Therefore, the GABAergic contribution to baseline $\mathrm{Ca}^{2+}{ }_{\mathrm{c}}$ levels requires constitutive synthesis of $\mathrm{GABA}$, which is released to act in an autocrine manner at both $\mathrm{GABA}_{\mathrm{A}}$ and $\mathrm{GABA}_{\mathrm{B}}$ receptors.

We also used furosemide, which blocks $\mathrm{Na}-\mathrm{K}-2 \mathrm{Cl}$ cotransporter activity, to demonstrate the critical importance of the physiological $\mathrm{Cl}^{-}$gradient in the contribution of GABA to baseline $\mathrm{Ca}^{2+}{ }_{\mathrm{c}}$ levels. Furosemide decreased $\mathrm{Ca}^{2+}{ }_{\mathrm{c}}$ levels in all of the $26 \mathrm{SP}$ $\mathrm{TnTx}^{\mathrm{hi}}$ neurons studied by $43 \pm 5 \mathrm{~nm}$ with a delayed and gradual time course (Fig. 9C), similar to that recorded with 3-MPA (Fig. $9 B$ ). These effects were partially reversible over 5-10 min.

Nitrendipine, which blocks voltage-dependent L-type $\mathrm{Ca}^{2+}$ channels, decreased $\mathrm{Ca}^{2+}{ }_{\mathrm{c}}$ levels of SP-TnTx ${ }^{\text {hi }}$ neurons with a time course similar to that recorded with $\mathrm{GABA}_{\mathrm{A}}$ receptor an- tagonists, indicating that baseline $\mathrm{Ca}^{2+}{ }_{\mathrm{c}}$ levels involved $\mathrm{Ca}^{2+}{ }_{\mathrm{o}}$ entry via L-type $\mathrm{Ca}^{2+}$ channels, which were opened by the depolarization resulting from the autocrine activation by GABA of $\mathrm{GABA}_{\mathrm{A}}$ receptor/ $\mathrm{Cl}^{-}$channels (Fig. 9D). In 27 neurons studied, nitrendipine decreased their baseline $\mathrm{Ca}^{2+}{ }_{\mathrm{c}}$ by $57 \pm 5 \mathrm{nM}$ and blocked evokable $\mathrm{Ca}^{2+}$ entry mediated by $\mathrm{K}^{+}$-induced depolarization.

In a parallel series of experiments, we investigated the possible contribution of ionotropic glutamate receptors and voltagedependent $\mathrm{Na}^{+}$channels to tonic $\mathrm{Ca}^{2+}{ }_{c}$ signaling of SP-TnTx ${ }^{\text {hi }}$ neurons, because these forms of excitability are increasingly expressed in differentiating cortical neurons (Maric et al., 2000b). Superfusion with CNQX and APV, respective antagonists at the AMPA/kainate and NMDA receptors, and TTX, a blocker of voltage-sensitive $\mathrm{Na}^{+}$action potentials, did not affect baseline $\mathrm{Ca}^{2+}{ }_{\mathrm{c}}$ levels of the 26 neurons recorded in NPM, whereas all exhibited sensitivity to bicuculline and picrotoxin (data not shown). Taken together, these results indicated that GABAergic signaling via $\mathrm{GABA}_{\mathrm{A}}$ autoreceptor $/ \mathrm{Cl}^{-}$channels dominates the baseline properties of differentiating embryonic cortical neurons independently of the other expressed forms of membrane excitability.

\section{Autocrine GABAergic signaling is critical to neurite outgrowth}

The emergence of functional GABAergic-signaling components among differentiating $\mathrm{CP} / \mathrm{SP}$ neurons and their capacity to release GABA from both cell body and growth cone compartments suggested that some form(s) of GABAergic signaling may occur during neurite outgrowth. We therefore investigated the possible 

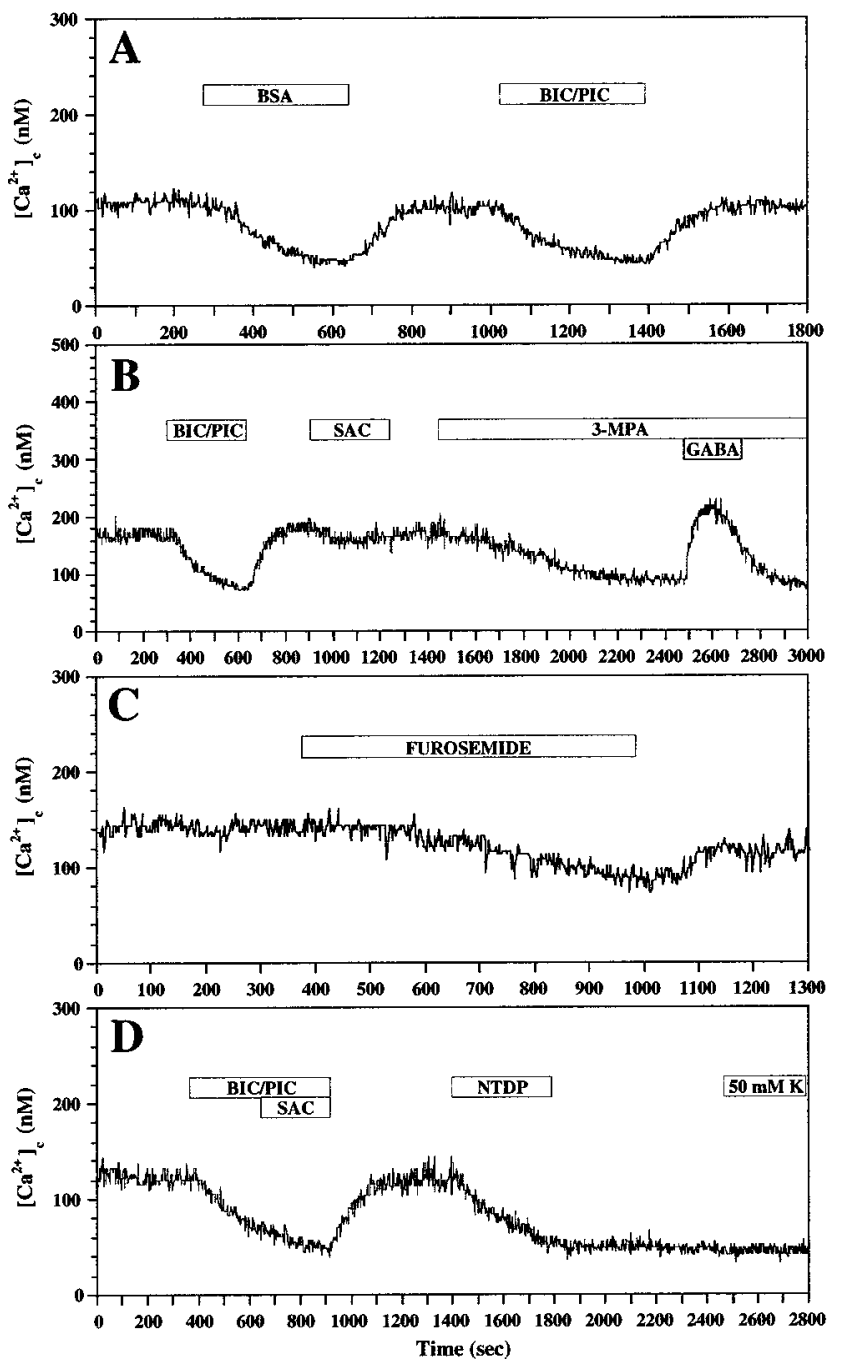

Figure 9. GAD-derived GABA acting at $\mathrm{GABA}_{\mathrm{A}}$ and $\mathrm{GABA}_{\mathrm{B}}$ receptors sustains $\mathrm{Ca}^{2+}{ }_{\mathrm{c}}$ levels in $\mathrm{CP} / \mathrm{SP}$ neurons via $\mathrm{L}$-type $\mathrm{Ca}^{2+}$ channels. $\mathrm{Ca}^{2+}$ imaging with fura- 2 was performed on SP-TnTx ${ }^{\text {hi }}$ neurons, which were cultured for $24 \mathrm{hr}$ and immunoidentified post hoc. The cells were continuously superfused with NPM before and during pharmacological manipulation (indicated by open horizontal bars). A, Exposure to BSA (1 $\mathrm{mg} / \mathrm{ml}$ ) mimics the depressant effects of $100 \mu \mathrm{M}$ BIC and $100 \mu \mathrm{M}$ PIC on baseline $\mathrm{Ca}^{2+}{ }_{\mathrm{c}}$ levels both in monoexponential time courses and the extent of depression and recovery. $B, \mathrm{SAC}(100 \mu \mathrm{M})$, the $\mathrm{GABA}_{\mathrm{B}}$ receptor antagonist, also depresses baseline $\mathrm{Ca}^{2+}{ }_{\mathrm{c}}$ levels but less effectively than BIC/PIC. Inclusion of 3-MPA (1 mM), which blocks GAD synthesis of GABA, slowly and persistently decreases baseline $\mathrm{Ca}^{2+}{ }_{\mathrm{c}}$ levels but does not prevent the $\mathrm{Ca}^{2+}{ }_{c}$ response to $10 \mu \mathrm{M}$ GABA. $C$, Furosemide $(1 \mathrm{~mm})$, which blocks $\mathrm{Na}-\mathrm{K}-2 \mathrm{Cl}$ cotransporter activity, slowly decreases $\mathrm{Ca}^{2+}$, which partially recovers during washing. $D$, NTDP $(10 \mu \mathrm{M})$, which blocks voltage-dependent $\mathrm{L}$-type $\mathrm{Ca}^{2+}$ channels, decreases $\mathrm{Ca}^{2+}{ }_{c}$ with the same time course and to the same extent as does the combination of BIC/PIC/ $\mathrm{SAC}$, but the effects persist and prevent any $\mathrm{Ca}^{2+}{ }_{\mathrm{c}}$ response to $50 \mathrm{mM} \mathrm{K}^{+}{ }_{\mathrm{o}}$, implicating $\mathrm{L}$-type $\mathrm{Ca}^{2+}$ channels in sustaining baseline $\mathrm{Ca}^{2+}{ }_{\mathrm{c}}$ levels.

physiological roles of GABAergic signaling during the earliest stages of neuronal process formation and regeneration. CP/SP neurons were cultured for 2-9 d in Neurobasal/B27 medium, which permitted optimal neurite outgrowth and recovery from dissociation. Over the first $48 \mathrm{hr}$, the majority of neurons developed well differentiated processes (Fig. 10A1), with an average total neurite length of $36 \pm 3 \mu \mathrm{m}$ (mean $\pm \mathrm{SEM} ; n=30$ ), and exhibited abundant GABA immunoreactivity (Fig. 10A2). Addi-
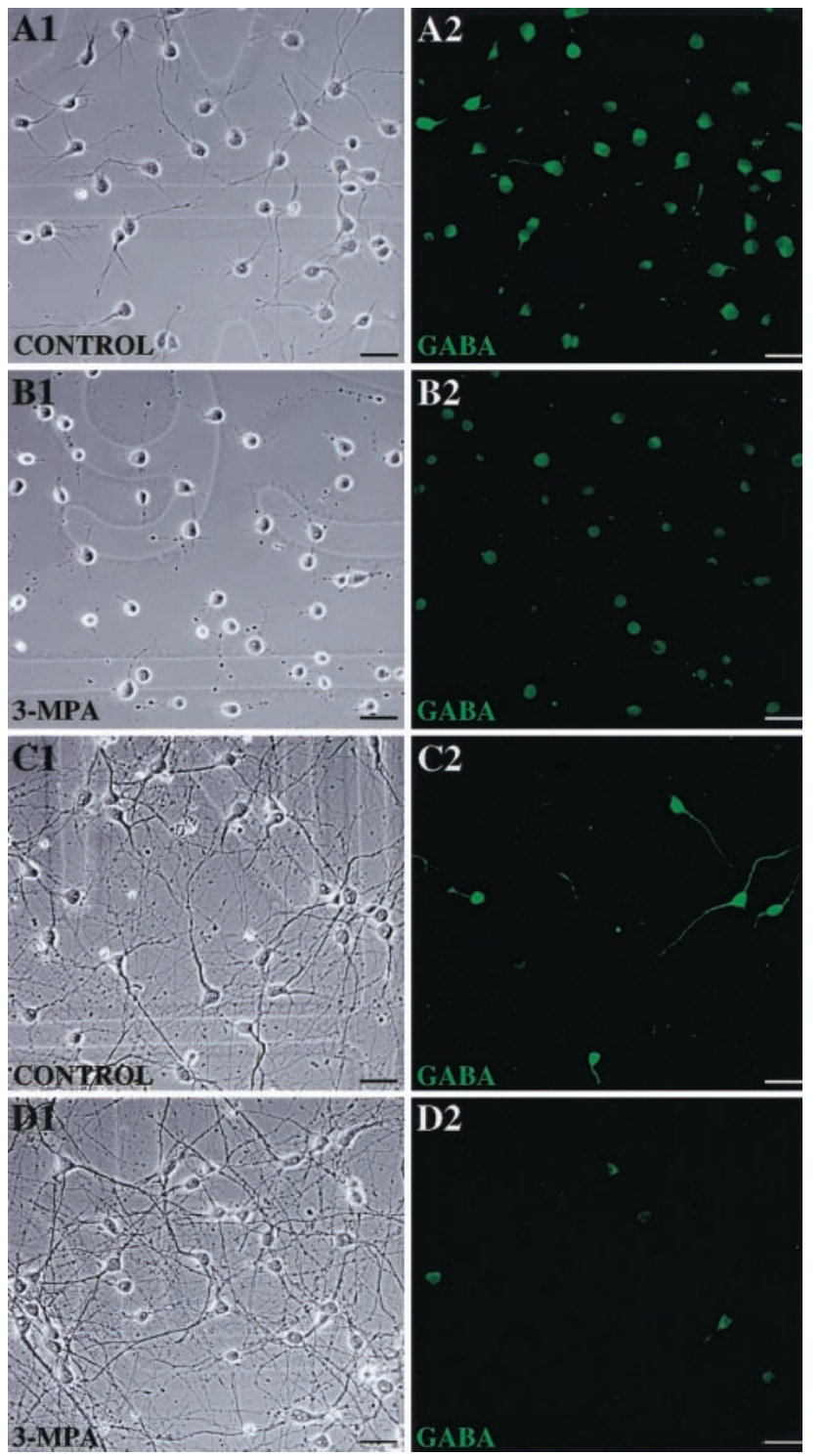

Figure 10. GAD-derived GABA is critical to neurite outgrowth in $\mathrm{CP} / \mathrm{SP}$ neurons, but its expression and modulatory effects are transient. $\mathrm{CP} / \mathrm{SP}$ neurons were cultured for 2 or $9 \mathrm{~d}$ in Neurobasal/B27 medium (control). Some preparations were treated with $100 \mu \mathrm{M}$ 3-MPA for 48 $\mathrm{hr}$ before termination of culture. The cells were then fixed in PF and processed for anti-GABA immunofluorescence staining, which was arbitrarily quantified using the Attofluor RatioVision acquisition software (Atto Instruments). The total length of neurites was calculated from phase-contrast images using the NIH Image Analysis software. To examine cell viability and cytotoxic effects of 3-MPA, companion plates were processed separately with a live/dead staining kit (Molecular Probes). A1, Under control conditions all neurons exhibit extensive process formation with each neuron forming more than one process. A2, Virtually all of the neurons are GABA immunopositive (green fluorescence), as are many of their processes. B1, After 3-MPA treatment, most of the neurons survive after $2 \mathrm{~d}$ in culture (as confirmed from live/dead staining in the companion plate; data not shown) but extend much shorter processes. B2, Few of these neurons exhibit detectable GABA immunoreactivity, as would be expected from the 3-MPA-induced inhibition of GAD-derived GABA synthesis. C1, After $9 \mathrm{~d}$ in culture in control preparations, the neurite outgrowth has been primarily completed, and all neurons form integrated networks of processes. $C 2$, At this stage, $<20 \%$ of the neurons are GABA immunopositive. D1, Addition of $100 \mu \mathrm{M} 3$-MPA for $48 \mathrm{hr}$ before the end of culture does not have detectable effects on cell morphology. D2, However, the GABA immunoreactivity of the remaining GABAergic neurons is significantly reduced by 3 -MPA. Scale bar, $20 \mu \mathrm{m}$. 
tion of 3-MPA to block GABA synthesis at the beginning of culture produced approximately a $70 \%$ reduction in neurite outgrowth (Fig. 10B1), resulting in an average neurite length of $12 \pm$ $1 \mu \mathrm{m}($ mean $\pm \mathrm{SEM} ; n=25)$ and a threefold reduction of GABA immunoreactivity (Fig. 10B2). This effect was not caused by cytotoxicity, because comparable numbers of neurons survived in 3-MPA-treated preparations as did in control cultures (data not shown).

During initial neurite outgrowth over the first $24-48 \mathrm{hr}, \mathrm{Ca}^{2+}{ }_{\mathrm{c}}$ levels quantified in neurons under control conditions and in cultures treated with 3 -MPA revealed steady baselines of $126 \pm 9$ $\mathrm{nM}(n=30)$ and $45 \pm 3 \mathrm{nM}(n=31)$, respectively. Bicuculline and picrotoxin decreased $\mathrm{Ca}^{2+}{ }_{\mathrm{c}}$ by $56 \pm 6 \mathrm{nM}$ in these neurons under control conditions but only by $3 \pm 3 \mathrm{nM}$ in 3-MPA-treated neurons. Together, these results indicate that 3-MPA effectively attenuated synthesis of GABA by GAD, thus reducing levels of immunodetectable GABA in most neurons. These effects of 3-MPA practically eliminated the indirect contribution to baseline $\mathrm{Ca}^{2+}{ }_{c}$ levels. A reduced complement of $\mathrm{L}$-type $\mathrm{Ca}^{2+}$ channels persisted in the neurons exposed to 3-MPA, as manifested by a nearly twofold increase in $\mathrm{Ca}^{2+}{ }_{\mathrm{c}}$ (to $81 \pm 4 \mathrm{nM}$ ) after exposure to $50 \mathrm{~mm} \mathrm{KCl}$, which is markedly less than the peak $\mathrm{Ca}^{2+}$ c response to $50 \mathrm{~mm} \mathrm{KCl}$ in $\mathrm{CP} / \mathrm{SP}$ neurons cultured in control conditions. This reduction in peak $\mathrm{Ca}^{2+}{ }_{\mathrm{c}}$ response to $\mathrm{KCl}$ may reflect the marked attenuation in neurite outgrowth and membrane surface area where functional L-type $\mathrm{Ca}^{2+}$ channels could have become incorporated.

By $9 \mathrm{~d}$ in culture, neurite formation was primarily completed (Fig. 10C1), and the number of GABAergic neurons markedly decreased (Fig. 10C2). Furthermore, the facilitating effect of GAD-derived GABA on process formation became nominal, because the remaining GABAergic neurons, which exhibited extensive neurite outgrowth after $9 \mathrm{~d}$ in culture, did not show detectable sensitivity to 3-MPA (Fig. 10D1), even after a marked reduction in GABA synthesis (Fig. 10D2). These findings suggest that GAD-derived GABA was not required to maintain neurite outgrowth after outgrowth was completed.

In a parallel set of experiments, we also selectively blocked other components, which we identified in the autocrine GABAergic-signaling circuit, to reveal their possible roles in neurite outgrowth (Fig. 11). Mean total neurite length obtained under control conditions after $48 \mathrm{hr}$ of culture in Neurobasal/B27 medium (37 $\pm 3 \mu \mathrm{m} ; n=31)$ was effectively reduced with bicuculline $(20 \pm 2 \mu \mathrm{m} ; n=40)$, picrotoxin $(17 \pm 2 \mu \mathrm{m} ; n=43)$, furosemide $(11 \pm 1 \mu \mathrm{m} ; n=42)$, or nitrendipine $(12 \pm 1 \mu \mathrm{m} ; n=$ 51 ), although comparable numbers of neurons consistently survived in three independent experiments of each condition as did in the control (data not shown). Furosemide and nitrendipine closely mimicked the effects of 3-MPA in reducing total neurite outgrowth by $\sim 70 \%$ (Fig. $11 E, F$ ), whereas bicuculline and picrotoxin were slightly less effective, attenuating total neurite outgrowth by $\sim 50 \%$ (Fig. $11 B, C$ ).

The possible contribution of $\mathrm{GABA}_{\mathrm{B}}$ receptor-coupled functions to neurite outgrowth was investigated by incubating $\mathrm{CP} / \mathrm{SP}$ neurons in saclofen, which modestly decreased baseline $\mathrm{Ca}^{2+}$ levels (Fig. 9B). Saclofen had no significant effects on neurite outgrowth $(36 \pm 3 \mu \mathrm{m} ; n=68)$ compared with that of control (Fig. 11A,D). Furthermore, exposure to CNQX, APV, atropine, suramin, and/or TTX did not alter baseline $\mathrm{Ca}_{\mathrm{c}}{ }^{2+}$ levels of $\mathrm{CP} / \mathrm{SP}$ neurons or affect neurite outgrowth of these cells (data not shown).

Taken together, these pharmacological results implicate

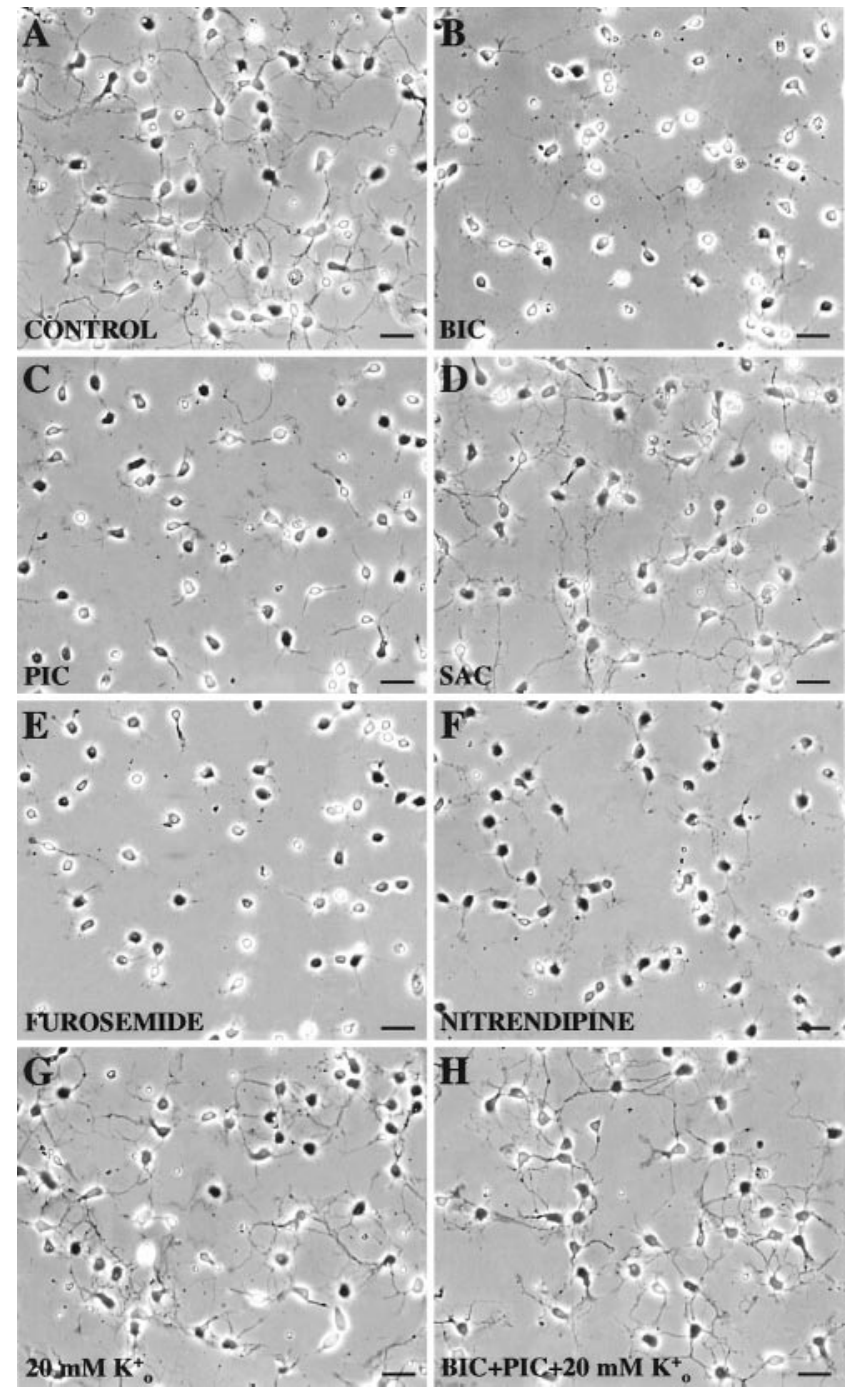

Figure 11. Autocrine GABAergic signaling is critical to neurite outgrowth, but it can be mimicked using $\mathrm{KCl}$ depolarization. $\mathrm{CP} / \mathrm{SP}$ neurons were cultured for $48 \mathrm{hr}$ under control or experimental conditions. The cells were then fixed, and their neurite length was quantified as described in Figure 10. $A$, Under control conditions in Neurobasal/B27 medium, all neurons project one or more neurites. $B-F$, Inclusion of either $100 \mu \mathrm{M}$ BIC $(B), 100 \mu \mathrm{M}$ PIC $(C), 100 \mu \mathrm{M}$ furosemide $(E)$, or $10 \mu \mathrm{M}$ nitrendipine $(F)$ in the culture medium over $48 \mathrm{hr}$ effectively attenuates neurite outgrowth in the majority of neurons, as illustrated in representative fields, whereas $100 \mu \mathrm{M}$ SAC $(D)$ has no significant effects. $G, H$, Inclusion of 20 mM $\mathrm{KCl}$ preserves neurite outgrowth in neurons whose $\mathrm{GABA}_{\mathrm{A}}$ receptor/ $\mathrm{Cl}^{-}$channels have been blocked by $100 \mu \mathrm{M}$ bicuculline and $100 \mu \mathrm{M}$ picrotoxin $(H)$, whereas $20 \mathrm{~mm} \mathrm{KCl}$ by itself has no significant effects on neurite outgrowth $(G)$ compared with control. Live/dead staining (see legend of Fig. 10) in the companion plates of each of the above conditions did not show significant differences in cell viability (data not shown). Scale bar, $20 \mu \mathrm{m}$.

GABA ${ }_{\mathrm{A}}$ receptor $/ \mathrm{Cl}^{-}$channels, $\mathrm{Cl}^{-}$cotransporter activity, and L-type $\mathrm{Ca}^{2+}$ channels in the autocrine GABAergic circuit that facilitates the initial stages of process formation and/or regeneration. However, after $7 \mathrm{~d}$ or more in culture when neurite outgrowth had become quite extensive and many neurites made visible contact with each other, pharmacological interruption of the circuit for 24-48 hr had no apparent effects on either $\mathrm{Ca}^{2+}{ }_{\mathrm{c}}$ levels or morphology (data not shown, but the results resembled those in Fig. 10C1,D1). In addition, GABA immunoreactivity 
gradually disappeared from most neurons over $7 \mathrm{~d}$, beginning at the cell body and then continuing at the process level and ending at the terminals (data not shown, but see Fig. 10C2). Thus, the autocrine GABAergic signaling decreased progressively as $\mathrm{CP} / \mathrm{SP}$ neurons differentiated extensive neurites.

\section{Neurite outgrowth can be preserved in the absence of GABAergic signaling by activating L-type $\mathrm{Ca}^{2+}$ channels}

We interrupted autocrine GABAergic signaling at $\mathrm{GABA}_{\mathrm{A}}$ receptor $/ \mathrm{Cl}^{-}$channel activation and then depolarized $\mathrm{CP} / \mathrm{SP}$ neurons by adding $20 \mathrm{~mm} \mathrm{KCl}$ to the growth medium, because this approximated the $\mathrm{Ca}^{2+}{ }_{\mathrm{c}}$ level sustained by autocrine GABAergic signaling after $24-48 \mathrm{hr}$ in culture (see Fig. 8). Neurons exposed to both bicuculline and picrotoxin exhibited the same degree of attenuation in process formation (data not shown) as seen with either alone (Fig. 11B,C). Inclusion of $20 \mathrm{~mm} \mathrm{KCl}$ in the medium along with bicuculline and picrotoxin preserved process formation and/or regeneration (Fig. $11 H$ ), with the mean neurite length (35 $\pm 3 \mu \mathrm{m} ; n=40)$ and cellular morphologies closely approximating those evident in control (Fig. 11A) or in control plus 20 mм KCl (Fig. 11G), in which the mean neurite length amounted to $37 \pm 3 \mu \mathrm{m}(n=31)$ and $39 \pm 3 \mu \mathrm{m}(n=49)$, respectively. Degrees of neuritogenesis similar to those seen in control were found when $20 \mathrm{~mm} \mathrm{KCl}$ was included with either 3-MPA or furosemide (data not shown), but not with nitrendipine, the outcome of which resembled that in Figure $11 F$, presumably because the nitrendipine blocked $\mathrm{Ca}^{2+}$ entry via activated L-type $\mathrm{Ca}^{2+}$ channels (see Fig. 9D). These results indicate that activation of L-type $\mathrm{Ca}^{2+}$ channels is the critical downstream mechanism for promoting neurite outgrowth in $\mathrm{CP} / \mathrm{SP}$ neurons.

\section{GABAergic signaling during neurite outgrowth does not involve vesicular release}

To investigate further the mechanisms of GABA release, we examined the subcellular distribution of GABA in differentiating $\mathrm{CP} / \mathrm{SP}$ neurons during the period of neurite recovery after dissociation. The cells were cultured for $24 \mathrm{hr}$ and examined for GABA expression using an immunogold reaction followed by silver enhancement and electron microscopy. The results typically revealed nonuniform distributions of GABA in the cytoplasm of the cell bodies and growth cones, with some clustering of the immunoreaction product apparent in subplasmalemmal regions (Fig. 12). There was little evidence of GABA compartmentalization in vesicles. Discrete small vesicular organelles arranged near the surface membrane, which are characteristic of those containing GABA at well developed synapses of fast-transmitting neurons, were noticeably absent. Thus, the autocrine GABAergicsignaling circuit expressed by embryonic $\mathrm{CP} / \mathrm{SP}$ neurons does not appear to involve vesicular exocytosis. Instead, alternate mechanisms of GABA release, including those that involve GABA transporters, may play a role, and elucidating them will be the goal of future investigations.

\section{DISCUSSION}

\section{Salient findings}

In this study we investigated the morphogenic role of GABA during neuronal differentiation in the rat embryonic neocortex. GABAergic-signaling components, including the expression of

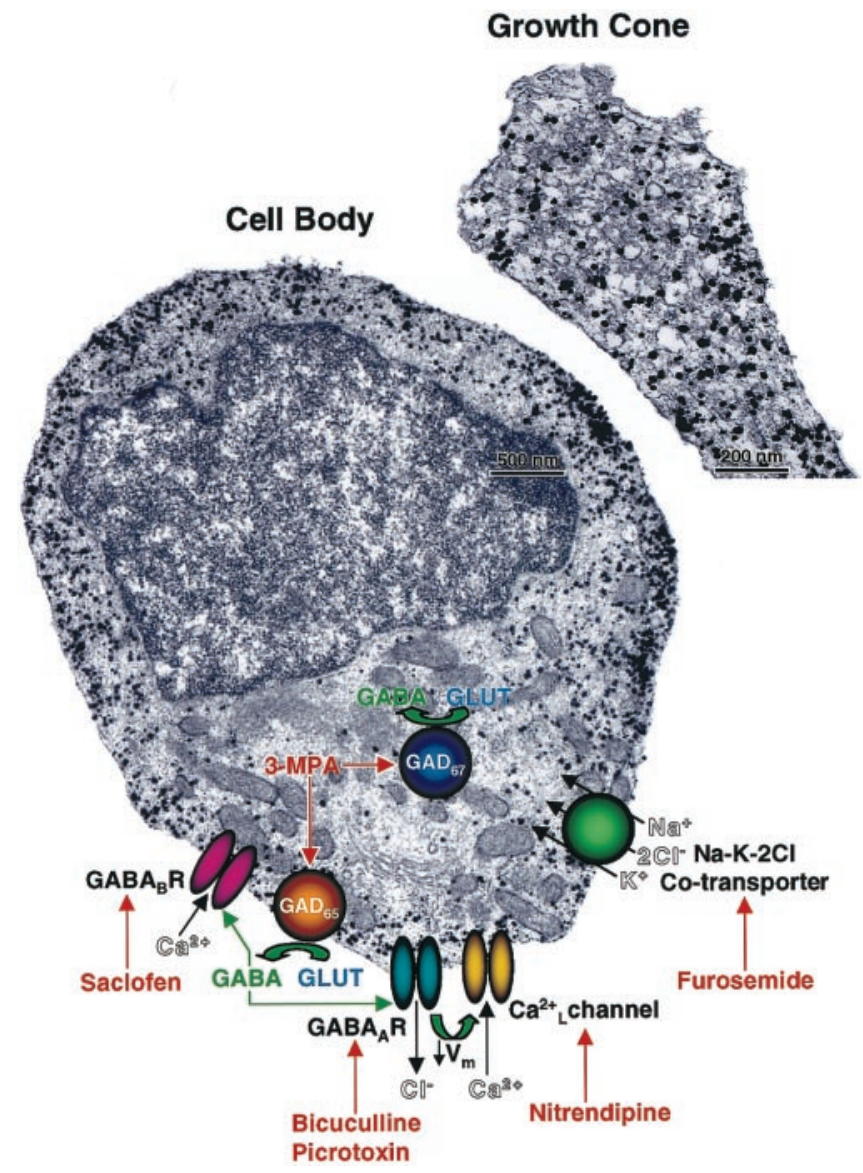

Figure 12. Subcellular distribution of GABA and a model of GABAergic-signaling pathways in a differentiating CP/SP neuron. CP/SP neurons were cultured for $24 \mathrm{hr}$ in Neurobasal/B27 and then fixed in PF and processed for immunoelectron microscopy using colloidal goldconjugated anti-GABA antibody followed by silver enhancement (see Materials and Methods for details). GABA immunoreaction (black particles) is nonuniformly distributed throughout the cytoplasm of the cell body with clusters evident in subplasmalemmal spaces. Similar distribution of GABA immunoreaction and the absence of transmitter-containing vesicles are observed in the growth cones of these neurons. Superimposed on the image of the cell body is a model summarizing the different components identified in this study, which compose the autocrine GABAergic circuit mediating the early phase of neurite outgrowth. GLUT, L-glutamate; $\mathrm{Ca}^{2+}{ }_{L}$, voltage-dependent L-type $\mathrm{Ca}^{2+}$ channel.

$\mathrm{GAD}_{65}, \mathrm{GAD}_{67}, \mathrm{GABA}, \mathrm{GABA}_{\mathrm{A}}$, and $\mathrm{GABA}_{\mathrm{B}}$ receptor subunits, and $\mathrm{GABAergic}$ signals at $\mathrm{GABA}_{\mathrm{A}}$ receptor/ $\mathrm{Cl}^{-}$channels emerged at the earliest stages of neuronal lineage progression in the VZ/SVZ. After radial migration to the CP/SP, the majority of differentiating neurons exhibited autocrine GABAergic signals, which dominated their baseline membrane potential and indirectly their $\mathrm{Ca}^{2+}{ }_{c}$ levels via $\mathrm{Ca}^{2+}$ entry through $\mathrm{L}$-type $\mathrm{Ca}^{2+}$ channels. This autocrine GABAergic circuit was critical to neurite outgrowth, because interruption of its individual components including GABA synthesis, $\mathrm{GABA}_{\mathrm{A}}$ receptor activation, intracellular $\mathrm{Cl}^{-}$ion homeostasis, or L-type $\mathrm{Ca}^{2+}$ channel activation markedly attenuated neurite outgrowth in most GABAergic neurons. In the absence of the autocrine GABAergic signaling, neuritogenesis of these cells could be preserved by $\mathrm{K}^{+}{ }_{\mathrm{o}}$-induced depolarization of their plasma membranes and activation of L-type $\mathrm{Ca}^{2+}$ channels, suggesting that $\mathrm{Ca}^{2+}$ entry is the critical factor in sustaining neurite outgrowth of these cells. 
GABAergic signaling at $\mathrm{GABA}_{\mathrm{A}}$ autoreceptors emerges among most postmitotic cortical neurons during neurogenesis and dominates their membrane potential

We have shown previously that, during neocortical development, the majority of postmitotic neurons are polarized at negative potentials, primarily according to a $\mathrm{K}^{+}$ion gradient (Maric et al., 1998c), and that most of these cells express $\mathrm{GABA}_{\mathrm{A}}$ receptors and depolarize to GABA via $\mathrm{Cl}^{-}$-dependent and bicucullineand/or picrotoxin-sensitive mechanisms (Maric et al., 2000b). To study these mechanisms pharmacologically, using exogenous applications of $\mathrm{GABA}_{\mathrm{A}}$ receptor agonists and antagonists, we found it necessary to supplement all recording solutions with $1 \mathrm{mg} / \mathrm{ml}$ BSA, because it effectively eliminated the contribution of endogenous GABAergic signaling from differentiating neurons and thus stabilized baseline membrane potentials for the duration of the experiments. In this study, however, we have also focused our investigation on the physiological roles of endogenous GABA on neuronal development and have therefore omitted BSA from the recording solutions. As expected, omission of BSA depolarized and elevated $\mathrm{Ca}^{2+}{ }_{\mathrm{c}}$ levels in many differentiating $\mathrm{CP} / \mathrm{SP}$ neurons, virtually all of which were $\mathrm{GAD}^{+}$and $\mathrm{GABA}^{+}$. These effects could be predominantly attenuated by the $\mathrm{GABA}_{\mathrm{A}}$ receptor $/ \mathrm{Cl}^{-}$ channel antagonists bicuculline and picrotoxin, by furosemide, which blocks $\mathrm{Cl}^{-}$ion transport into cells, and by 3-MPA, which blocks GAD activity.

The autocrine GABAergic signaling primarily involved spontaneous, random openings of $\mathrm{GABA}_{\mathrm{A}}$ receptor $/ \mathrm{Cl}^{-}$channels, whereas the contribution of $\mathrm{GABA}_{\mathrm{B}}$ receptors was minor. Baseline properties dominated by GABA in embryonic $\mathrm{CP} / \mathrm{SP}$ neurons gradually disappeared after $7 \mathrm{~d}$ in culture consistent with a transient role for autocrine signaling during neurite outgrowth (Maric and Barker, unpublished observations). GABAergic baseline signals involving $\mathrm{GABA}_{\mathrm{A}}$ receptors have been recorded previously both in cultured embryonic hippocampal neurons (Valeyev et al., 1993, 1998) and in early postnatal hippocampal neurons in slices (Ben-Ari et al., 1989). The slice experiments demonstrated that bicuculline-sensitive GABAergic baselines disappear at the end of the first postnatal week as hyperpolarizing GABAergic transient signals emerge.

Spectral analysis revealed that most $\mathrm{Cl}^{-}$channel openings involved estimated burst-length durations of $\sim 100 \mathrm{msec}$, similar to those estimated for GABA-induced $\mathrm{Cl}^{-}$currents in newly adherent embryonic cortical neurons without processes (Serafini et al., 1998). Thus, the same channel properties predominate both before and during neurite outgrowth. The similarities in the kinetics of baseline and GABA-activated channels strongly suggest that (1) GABA rather than other substances mediates the baseline $\mathrm{Cl}^{-}$channel activity and (2) submicromolar to micromolar concentrations in solution mimic the intensity of the autocrine GABAergic signal. Superfusion eliminated the baseline current, demonstrating that it was mediated by GABA equilibrating in a surface-accessible compartment, which is consistent with results in embryonic hippocampal neurons (Valeyev et al., 1993, 1998; Vautrin et al., 2000). Channel activity during superfusion most likely reflected autocrine signaling at the neuronal surface apposing the coverslip, which would be less accessible to superfusion and similar to the interstitial space. Hence, low numbers of randomly activated $\mathrm{GABA}_{\mathrm{A}}$ autoreceptor $/ \mathrm{Cl}^{-}$channels were sufficient to dominate resting potentials of most embryonic $\mathrm{CP} / \mathrm{SP}$ neurons in vitro. We have shown previously that exogenous activation of low numbers $(<5)$ of $\mathrm{GABA}_{\mathrm{A}}$ receptor/
$\mathrm{Cl}^{-}$channels in intact embryonic hippocampal neurons could exert shifts in their membrane potential by $5-10 \mathrm{mV}$ (Maric et al., 1999b).

\section{$\mathrm{GABA}_{\mathrm{A}}$ receptor subunit expression patterns change as postmitotic neurons migrate from the VZ/SVZ to the CP/SP region}

Our data demonstrated that the potency of muscimol at $\mathrm{GABA}_{\mathrm{A}}$ receptor $/ \mathrm{Cl}^{-}$channels increased during neuronal lineage progression. This increase may be related to the developmentally changing subunit patterns and their intrinsic properties and/or to receptor densities. In this regard, approximately the same percentages of $\mathrm{TnTx}^{-} \mathrm{A} 2 \mathrm{~B} 5^{-}$precursor cells and SP-TnTx ${ }^{\mathrm{lo}}$ and DP-TnTx ${ }^{10}$ neuronal progenitors depolarized as expressed $\alpha 4$, $\beta 1$, or $\gamma 1$ subunits, whereas a great majority of both SP-TnTx ${ }^{\text {hi }}$ and DP-TnTx ${ }^{\text {hi }}$ differentiating neurons depolarized, which was comparable with those that expressed either $\alpha 3, \beta 3$, $\gamma 2$, or $\gamma 3$ subunits. Thus, the predominant $\mathrm{GABA}_{\mathrm{A}}$ receptor subunits, $\alpha 4$, $\beta 1$, and $\gamma 1$ in precursors and progenitors or $\alpha 3, \beta 3, \gamma 2$, and $\gamma 3$ in differentiating neurons, are probably coexpressed and form functional $\mathrm{Cl}^{-}$channels.

The potentiometric results can be compared with an electrophysiological study on $\mathrm{GABA}_{\mathrm{A}}$ receptor-mediated signaling using whole-cell recording (Owens et al., 1999). The authors found that (1) all of the embryonic cortical cells sampled exhibited functional $\mathrm{GABA}_{\mathrm{A}}$ receptors and (2) $\mathrm{EC}_{50}$ values for activating macroscopic $\mathrm{Cl}^{-}$currents shifted from $\sim 5 \mu \mathrm{M}$ in VZ cells to $\sim 28 \mu \mathrm{M}$ in CP neurons, whereas Hill coefficients decreased from $\sim 2$ to $\sim 1$. The authors also reported that isolated $\mathrm{VZ}$ cells exhibited few functional $\mathrm{GABA}_{\mathrm{A}}$ receptor/ $\mathrm{Cl}^{-}$channels $(<5)$. Thus, the phenotyped VZ/SVZ subpopulations studied here likely express limited numbers of functional $\mathrm{GABA}_{\mathrm{A}}$ receptor $/ \mathrm{Cl}^{-}$channels. However, these could dominate membrane potential and, indirectly, $\mathrm{Ca}^{2+}{ }_{\mathrm{c}}$ levels, thereby affecting neuronal progenitor proliferation (LoTurco et al., 1995). The $\mathrm{EC}_{50}$ values measured electrophysiologically among $\mathrm{VZ}$ and $\mathrm{CP}$ neurons contrast with those found using potentiometry, which shifted from approximately micromolar in VZ/SVZ cells to submicromolar in CP/SP neurons. The Hill coefficient in $\mathrm{CP}$ neurons also differed from that determined potentiometrically, which remained $\sim 2$. These differences could be related to the different recording strategies and endpoints and/or to the sample sizes, which are relatively limited in patch-clamp studies. Furthermore, if $\mathrm{GABA}_{\mathrm{A}}$ receptor/ $\mathrm{Cl}^{-}$ channels are regulated by soluble components of signal transduction pathways in the cytoplasm [for review, see Moss and Smart (1996)], then these components could be diluted in whole-cell recordings and thus conceivably alter $\mathrm{GABA}_{\mathrm{A}}$ receptor affinity. Perforated-patch recordings would show whether this helps to explain the differences in the pharmacological parameters derived from electrical and optical recordings.

\section{GABAergic signaling at $\mathrm{GABA}_{\mathrm{A}}$ autoreceptor $/ \mathrm{Cl}^{-}$ channels expressed by CP/SP neurons mediates neurite outgrowth via activation of L-type $\mathrm{Ca}^{2+}$ channels}

Block of the autocrine GABAergic-signaling circuit attenuated neurite outgrowth in most, but not all, GABAergic CP/SP neurons. These results are consistent with reports implicating $\mathrm{GABA}_{\mathrm{A}}$ receptor $/ \mathrm{Cl}^{-}$channels in the process formation of neurons cultured from different CNS regions and species (Michler, 1990; Barbin et al., 1993; Bird and Owen, 1998). However, both facilitatory and inhibitory effects of GABA on neurite outgrowth have been reported, depending on cell type and culture condi- 
tions. HPLC studies showed that growth cones fractionated from the postnatal rat cortex release endogenous GABA spontaneously before the emergence of synaptic vesicle-related proteins and that this release is increased after superfusion with $\mathrm{Ca}^{2+}{ }_{\text {o-free saline }}$ and enhanced still further by $25 \mathrm{mM} \mathrm{KCl}$ (Taylor et al., 1990). The mechanisms underlying release of endogenous GABA from postnatal growth cones and the regulatory role of extracellular $\mathrm{Ca}^{2+}$ in this process have yet to be elucidated. In our experiments, GABA release from embryonic CP/SP neuronal cell bodies and growth cones was $\mathrm{Ca}^{2+}$ dependent. These results suggest a positive feedback loop in the autocrine circuit with $\mathrm{Ca}^{2+}$-dependent GABA release activating $\mathrm{Ca}^{2+}$ entry via $\mathrm{L}$-type $\mathrm{Ca}^{2+}$ channels and promoting GABA release. The loop most likely involves $\mathrm{Ca}^{2+}$-dependent regulation of GAD activities because constitutive synthesis of GABA was necessary to sustain activity in the autocrine circuit.

GABA release from axonal growth cones of embryonic mouse hypothalamic neurons has also been detected electrically (Gao and van den Pol, 2000), and exogenously applied GABA has been shown to elevate $\mathrm{Ca}^{2+}{ }_{c}$ in these growth cones via bicucullineand furosemide-sensitive mechanisms (Obrietan and van den Pol, 1996). Bicuculline also decreased ambient $\mathrm{Ca}^{2+}{ }_{\mathrm{c}}$ levels in hypothalamic neurons, which had been cultured for $6 \mathrm{~d}$. This was attributed to blockade of synaptically released GABA acting at $\mathrm{GABA}_{\mathrm{A}}$ receptors. The results of the present study reveal that the autocrine GABAergic circuit operates during the earliest stages of neurite outgrowth before functional synapses form. The intracellular pathway(s) that couples autocrine GABAergic signaling to neurite outgrowth likely involves $\mathrm{Ca}^{2+}$-dependent activation of (1) protein kinase $\mathrm{C}$ with subsequent phosphorylation of GAP-43 and Myristoyl alanine-rich protein kinase $\mathrm{C}$ substrate proteins (Fukura et al., 1996) and (2) degradation of spectrin and release of $\alpha$-actinin by calpain (Ohbayashi et al., 1998), which have both been identified as targets of GABAergic signaling in growth cones fractionated from the embryonic and early postnatal rat cortex. The dynamics regarding the complex interplay among the different components at membrane and cytoplasmic levels during neurite outgrowth and how the circuit is developmentally regulated remain to be elucidated.

\section{REFERENCES}

Altman J, Bayer SA (1995) Atlas of prenatal rat brain development. Boca Raton, FL: CRC.

Barbin G, Pollard H, Gaïarsa JL, Ben-Ari Y (1993) Involvement of $\mathrm{GABA}_{\mathrm{A}}$ receptors in the outgrowth of cultured hippocampal neurons. Neurosci Lett 152:150-154.

Barker JL, Lauder JM (1998) GABA as a trophic signal: perspectives in developmental neurobiology, Vol 5. Selangor Darul Ehsan, Malaysia: Overseas Publishers Association.

Behar TN, Li YX, Tran HT, Ma W, Dunlap V, Scott C, Barker JL (1996) GABA stimulates chemotaxis and chemokinesis of embryonic cortical neurons via calcium-dependent mechanisms. J Neurosci 16:1808-1818.

Behar TN, Schaffner AE, Scott CA, O'Connell C, Barker JL (1998) Differential response of cortical plate and ventricular zone cells to GABA as a migration stimulus. J Neurosci 18:6378-6387.

Behar TN, Schaffner AE, Scott CA, Greene CL, Barker JL (2000) GABA receptor antagonists modulate postmitotic cell migration in slice cultures of embryonic rat cortex. Cereb Cortex 10:899-909.

Ben-Ari Y, Cherubini E, Corradetti R, Gaiarsa JL (1989) Giant synaptic potentials in immature rat CA3 hippocampal neurones. J Physiol (Lond) 416:303-325.

Benke D, Cicin-Sain A, Mertens S, Mohler H (1991) Immunochemical identification of the alpha 1- and alpha 3-subunits of the $\mathrm{GABA}_{\mathrm{A}^{-}}$ receptor in rat brain. J Recept Res 11:407-424.

Benke D, Michel C, Mohler H (1997) GABA(A) receptors containing the alpha4-subunit: prevalence, distribution, pharmacology, and subunit architecture in situ. J Neurochem 69:806-814.

Bird M, Owen A (1998) Neurite outgrowth-regulating properties of GABA and the effect of serum on mouse spinal cord neurons in culture. J Anat 193:503-508.
Bowery NG, Enna SJ (2000) Gamma-aminobutyric acid(B) receptors: first of the functional metabotropic heterodimers. J Pharmacol Exp Ther 292:2-7.

Buchstaller A, Fuchs K, Sieghart W (1991) Identification of alpha 1-, alpha 2- and alpha 3-subunit isoforms of the $\mathrm{GABA}_{\mathrm{A}}$-benzodiazepine receptor in the rat brain. Neurosci Lett 129:237-241.

Calver AR, Medhurst AD, Robbins MJ, Charles KJ, Evans ML, Harrison DC, Stammers M, Hughes SA, Hervieu G, Couve A, Moss SJ, Middlemiss DN, Pangalos MN (2000) The expression of GABA(B1) and GABA(B2) receptor subunits in the CNS differs from that in peripheral tissues. Neuroscience 100:155-170.

Cobas A, Fairen A, Alvarez BG, Sanchez MP (1991) Prenatal development of the intrinsic neurons of the rat neocortex: a comparative study of the distribution of GABA-immunoreactive cells and the GABA $_{\mathrm{A}}$ receptor. Neuroscience 40:375-397.

Couve A, Moss SJ, Pangalos MN (2000) GABA(B) receptors: a new paradigm in $G$ protein signaling. Mol Cell Neurosci 16:296-312.

Durkin MM, Gunwaldsen CA, Borowsky B, Jones KA, Branchek TA (1999) An in situ hybridization study of the distribution of the GABA(B2) protein mRNA in the rat CNS. Brain Res Mol Brain Res 71:185-200.

Fukura H, Komiya Y, Igarashi M (1996) Signaling pathway downstream of $\mathrm{GABA}_{\mathrm{A}}$ receptor in the growth cone. J Neurochem 67:1426-1434.

Gao X-B, van den Pol AN (2000) GABA release from mouse axonal growth cones. J Physiol (Lond) 523 3:629-637.

Hamill OP, Marty A, Neher E, Sakmann B, Sigworth FJ (1981) Improved patch-clamp techniques for high-resolution current recording from cells and cell-free membrane patches. Pflügers Arch 391:85-100.

Haydar TF, Wang F, Schwartz ML, Rakic P (2000) Differential modulation of proliferation in the neocortical ventricular and subventricular zones. J Neurosci 20:5764-5774.

Hebel R, Stromberg MW (1986) Anatomy and embryology of the laboratory rat. Worthsee, Germany: Biomed Verlag.

Jones KA, Borowsky B, Tamm JA, Craig DA, Durkin MM, Dai M, Yao WJ, Johnson M, Gunwaldsen C, Huang LY, Tang C, Shen Q, Salon JA, Morse K, Laz T, Smith KE, Nagarathnam D, Noble SA, Branchek TA, Gerald C (1998) GABA $_{B}$ receptors function as a heteromeric assembly of the subunits $\mathrm{GABA}_{\mathrm{B}} \mathrm{R} 1$ and $\mathrm{GABA}_{\mathrm{B}} \mathrm{R} 2$. Nature 396:674-679.

Kaupmann K, Malitschek B, Schuler V, Heid J, Froestl W, Beck P, Mosbacher J, Bischoff S, Kulik A, Shigemoto R, Karschin A, Bettler B (1998) $\mathrm{GABA}_{\mathrm{B}}$-receptor subtypes assemble into functional heteromeric complexes. Nature 396:683-687.

Lauder JM, Han VKM, Henderson P, Verdoorn T, Towle AC (1986) Prenatal ontogeny of the GABAergic system in the rat brain: an immunocytochemical study. Neuroscience 19:465-493.

Laurie DJ, Wisden W, Seeburg PH (1992) The distribution of thirteen $\mathrm{GABA}_{\mathrm{A}}$ receptor subunit mRNAs in the rat brain. III. Embryonic and postnatal development. J Neurosci 12:4151-4172.

Liu QY, Schaffner AE, Barker JL (1999) Electrophysiological studies on receptors in vitro. In: Neuromethods, Vol 34 (Boulton AA, Baker GB, Bateson AN, eds), pp 37-318. Totowa, NJ: Humana.

LoTurco JJ, Owens DF, Heath MJS, Davis MBE, Kriegstein AR (1995) GABA and glutamate depolarize cortical progenitor cells and inhibit DNA synthesis. Neuron 15:1287-1298.

Ma W, Barker JL (1995) Complementary expressions of transcripts encoding $\mathrm{GAD}_{67}$ and $\mathrm{GABA}_{\mathrm{A}}$ receptor $\alpha 4, \beta 1$, and $\gamma 1$ subunits in the proliferative zone of the embryonic rat central nervous system. J Neurosci 15:2547-2560.

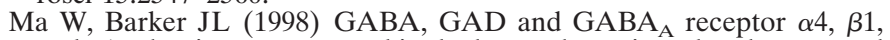
and $\gamma 1$ subunits are expressed in the late embryonic and early postnatal neocortical germinal matrix and coincide with gliogenesis. Microsc Res Tech 30:398-407.

Maric D, Maric I, Ma W, Lahojuji F, Somogyi R, Wen X, Sieghart W, Fritschy JM, Barker JL (1997) Anatomical gradients in proliferation and differentiation of embryonic rat CNS accessed by buoyant density fractionation: alpha 3 , beta 3 and gamma $2 \mathrm{GABA}_{\mathrm{A}}$ receptor subunit co-expression by post-mitotic neocortical neurons correlates directly with cell buoyancy. Eur J Neurosci 9:507-522.

Maric D, Maric I, Sieghart W, Fritschy J-M, Barker JL (1998a) Physiological properties of GABAergic neurons in the embryonic rat cortex are dominated by $\mathrm{GABA}_{\mathrm{A}}$ receptor/Cl ${ }^{-}$channel activity. Soc Neurosci Abstr 24:794.

Maric D, Maric I, Barker JL (1998b) Buoyant density gradient fractionation and flow cytometric analysis of embryonic rat cortical neurons and progenitor cells. Methods 16:247-259.

Maric D, Maric I, Smith SV, Serafini R, Hu Q, Barker JL (1998c) Potentiometric study of resting potential, contributing $\mathrm{K}^{+}$channels and the onset of $\mathrm{Na}^{+}$channel excitability in embryonic rat cortical cells. Eur J Neurosci 10:2532-2546.

Maric D, Maric I, Barker JL (1999a) Flow cytometric strategies to study CNS development. In: Neuromethods, Vol 33 (Boulton AA, Baker GB, eds), pp 287-318. Totowa, NJ: Humana.

Maric D, Maric I, Wen X-L, Fritschy J-M, Sieghart W, Barker JL, Serafini $R$ (1999b) GABA receptor subunit composition and functional prop- 
erties of $\mathrm{Cl}^{-}$channels with differential sensitivity to zolpidem in embryonic rat hippocampal cells. J Neurosci 19:4921-4937.

Maric D, Maric I, Barker JL (2000a) Developmental changes in cell calcium homeostasis during neurogenesis of the embryonic rat cerebral cortex. Cereb Cortex 10:561-573.

Maric D, Maric I, Chang Y-H, Barker JL (2000b) Stereotypic physiological properties emerge during early neuronal and glial lineage development in the embryonic rat neocortex. Cereb Cortex 10:729-747.

Marksitzer R, Benke D, Fritschy JM, Trzeciak A, Bannwarth W, Mohler

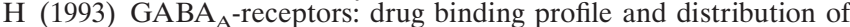
receptors containing the alpha 2-subunit in situ. J Recept Res 13:467-477.

Martin DL, Rimvall K (1993) Regulation of gamma-aminobutyric acid synthesis in the brain. J Neurochem 60:395-407.

Martin SC, Russek SJ, Farb DH (1999) Molecular identification of the human GABABR2: cell surface expression and coupling to adenylyl cyclase in the absence of GABABR1. Mol Cell Neurosci 13:180-191.

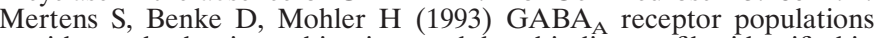
with novel subunit combinations and drug binding profiles identified in brain by alpha 5- and delta-subunit-specific immunopurification. J Biol Chem 268:5965-5973.

Michler A (1990) Involvement of GABA receptors in the regulation of neurite outgrowth in cultured embryonic chick tectum. Int $\mathrm{J}$ Dev Neurosci 8:463-472.

Moss SJ, Smart TG (1996) Modulation of amino acid-gated ion channels by protein phosphorylation. Int Rev Neurobiol 39:1-52.

Mossier B, Togel M, Fuchs K, Sieghart W (1994) Immunoaffinity purification of gamma-aminobutyric acid $\mathrm{A}\left(\mathrm{GABA}_{\mathrm{A}}\right)$ receptors containing gamma 1-subunits. Evidence for the presence of a single type of gamma-subunit in GABA receptors. J Biol Chem 269:25777-25782.

Obrietan K, van den Pol AN (1996) Growth cone calcium elevation by GABA. J Comp Neurol 372:167-175.

Ohbayashi K, Fukura H, Inoue HK, Komiya Y, Igarashi M (1998) Stimulation of L-type $\mathrm{Ca}^{2+}$ channel in growth cones activates two independent signaling pathways. J Neurosci Res 51:682-696.

Owens DF, Liu X, Kriegstein AR (1999) Changing properties of $\mathrm{GABA}_{A}$ receptor-mediated signaling during early neocortical development. J Neurophysiol 82:570-583.

Poulter MO, Barker JL, O'Carroll AM, Lolait SJ, Mahan LC (1992) Differential and transient expression of GABA receptor alpha-subunit mRNAs in the developing rat CNS. J Neurosci 12:2888-2900.

Poulter MO, Barker JL, O'Carrol AM, Lolait SJ, Mahan LC (1993) Coexistent expression of $\mathrm{GABA}_{\alpha}$ receptor $\beta 2, \beta 3$, and $\gamma 2$ subunits messenger RNAs during embryogenesis and early postnatal development of the rat central nervous system. Neuroscience 53:1019-1033.
Princivalle A, Regondi MC, Frassoni C, Bowery NG, Spreafico R (2000) Distribution of GABA(B) receptor protein in somatosensory cortex and thalamus of adult rats and during postnatal development. Brain Res Bull 52:397-405.

Rimvall K, Sheikh SN, Martin DL (1993) Effects of increased gammaaminobutyric acid levels on GAD67 protein and mRNA levels in rat cerebral cortex. J Neurochem 60:714-720.

Serafini R, Maric D, Maric I, Ma W, Fritschy JM, Zhang L, Barker JL (1998) Dominant $\mathrm{GABA}_{\mathrm{A}}$ receptor/ $\mathrm{Cl}^{-}$channel kinetics correlate with the relative expressions of $\alpha 2, \alpha 3, \alpha 5$ and $\beta 3$ subunits in embryonic rat neurones. Eur J Neurosci 10:334-349.

Sperk G, Schwarzer C, Tsunashima K, Fuchs K, Sieghart W (1997) GABA(A) receptor subunits in the rat hippocampus I: immunocytochemical distribution of 13 subunits. Neuroscience 80:987-1000.

Tanner VA, Ploug T, Tao-Cheng JH (1996) Subcellular localization of SV2 and other secretory vesicle components in PC12 cells by an efficient method of preembedding EM immunocytochemistry for cell cultures. J Histochem Cytochem 44:1481-1488.

Taylor J, Docherty M, Gordon-Weeks PR (1990) GABAergic growth cones: release of endogenous GABA precedes the expression of synaptic vesicle antigens. J Neurochem 54:1689-1699.

Todd AJ, Watt C, Spike RC, Sieghart W (1996) Colocalization of GABA, glycine, and their receptors at synapses in the rat spinal cord. J Neurosci 16:974-982.

Valeyev AY, Cruciani RA, Lange GD, Smallwood VS, Barker JL (1993) $\mathrm{Cl}-$ channels are randomly activated by continuous GABA secretion in cultured embryonic rat hippocampal neurons. Neurosci Lett 155:199-203.

Valeyev AY, Schaffner AE, Skolnick P, Dunlap VS, Wong G, Barker JL (1998) Embryonic rat hippocampal neurons and GABA receptor subunit-transfected non-neuronal cells release GABA tonically. J Membr Biol 164:239-251.

Van Eden CG, Mrzljak L, Voorn P, Uylings HBM (1989) Prenatal development of GABAergic neurons in the neocortex of the rat. J Comp Neurol 289:213-227.

Vautrin J, Maric D, Sukhareva M, Schaffner AE, Barker JL (2000) Surface-accessible GABA supports tonic and quantal synaptic transmission. Synapse 37:38-55.

White JH, Wise A, Main MJ, Green A, Fraser NJ, Disney GH, Barnes AA, Emson P, Foord SM, Marshall FH (1998) Heterodimerization is required for the formation of a functional $\mathrm{GABA}(\mathrm{B})$ receptor. Nature 396:679-682.

Yung KK, Ng TK, Wong CK (1999) Subpopulations of neurons in the rat neostriatum display GABABR1 receptor immunoreactivity. Brain Res 830:345-352. 